\title{
Şah ile Sultan Arasında Bir Acem Bürokratı: İdrîs-i Bidlîsı̂’nin Şah İsmail'in Himayesine Girme Çabası
}

Vural Genç

\author{
Mahpus olduğum kafesten kaçıp kurtulan kuş, benim \\ Simdi ise evlatlarımın ayrllık acısından zindanda gibiyim \\ Kullarının efendisi olan Şabin inayeti ve yardımıyla \\ Bütün müptelalar belalarından kurtulsa ne olur? \\ İdrîs-i Bidlîsî, Mekke 1512
}

A Persian Bureaucrat Between the Shah and the Sultan: İdrîs-i Bidlîsî̀s Attempt to Seek Shah Ismail's Patronage

Abstract Idrîs-i Bidlîsî (1457-1520) is undoubtedly one of the most original and important intellectual figures in the 16th-century Ottoman world. As a bureaucrat and historian of Iranian provenance, he lived in a very turbulent period of the Ottoman-Aqquyunlu, Ottoman-Mamluk and Ottoman-Safavid rivalry [rivalries] at the end of the 15th century and at the beginning of the 16th century. He established relationships at different times with each of these four dynasties which were hostile to each other. Although he is remembered for being under the patronage of Bayezid II and Selim I, in fact he attempted to seek patronage of different dynasties in this political atmosphere. No doubt one of the potential patrons was Shah Ismail. In the light of a recently discovered document this article discusses Bidlîsî̀ aim to find a new patron in the person of the Shah, an idea he conceived in Istanbul after leaving Bayezid II's patronage, during his sojourn in Mecca where he travelled for realizing this aim.

Keywords: Idrîs-i Bidlîsî, Shah Ismail, Bayezid II, Selim I, Ottomans, Safavids 
Şah İsmail, Akkoyunlu hanedanına son verdiğinde (1501) Tebriz'deki Heşt Behişt Sarayı'nda bulunan saray ekâbiri ve ülke genelindeki bir kısım ulema, şehrin Şah İsmail ile Akkoyunlu beyleri arasında birden fazla kez el değiştirmesinin getirdiği siyasi kaos ve istikrarsızlık ortamından çıkıp yeni bir hami bulmak adına İran'dan ayrıldılar. Mevcut siyasi teşekküllerin yıkılması sonucu ortaya çıkan kaos ve artık parlak medreseler ile ilmi merkezlerde buradaki ulemayı himaye edecek hamilerin bulunmayışı, bu ulema ve sanatkâr zümresinin başta Osmanlı olmak üzere Maveraünnehr ve Hint topraklarına göç etmelerine neden oldu. Bunlar arasından zengin hamiler olarak bilinen Osmanlı padişahlarının İran uleması ve sanatkârlarını himaye etmeleri, önemli payelere getirmeleri hatta zaman zaman mektuplar yazarak İstanbul'a davet etmeleri Osmanlı topraklarını onlar için daha cazip hale getirmişti. ${ }^{1}$ Öte yandan İran ile Osmanlı uleması arasındaki köklü ilişkiler Osmanlı topraklarına yönelik ulema zümresinin göçünde önemli bir rol oynadı. Bu göçlerle gelen ve İran'ın köklü medrese geleneğine sahip ilim ve sanat erbabı isimler, Osmanlıda saray tarihçiliği, has tabiplik, şehnamecilik, kazaskerlik

1 Osmanl-İran arasındaki ulema gidiş gelişini 1501 tarihinden önceye götürmek mümkündür. Osmanlılar ile Timurlular (Şahruh dönemi) arasında Timurluların son dönemlerine kadar sürecek olan dostane ilişkilerin en büyük kanıtı iki ülke arasında gidip gelen ulema hareketliliği idi. Timurlu İmparatorluğunun dağılmasının ardından Doğu İran'da (Horasan'ın büyük bir kısmı) Herat merkezli olarak müstakil bir şekilde hâkimiyetini sürdüren Sultan Hüseyin Baykara (875/1470-71-911/1505-06) hem son dönem Timurlu ulema ve sanatçılarının sığındığı güvenli bir idareci olmuş hem de bunun döneminde Osmanlı tarafından gidiş geliş yapan ulema hareketliliği Şahruh dönemine nazaran daha da artmıştı. Ayrıca Fatih'in, ilim ve sanat faaliyetlerini destekleyen ve ulemayı himaye eden birisi olarak, İran'da şöhret bulmuş olan ulemayı kendi yanına çekmek için onlarla irtibata geçtiği bilinmektedir. Onun bu çabaları sonuçsuz kalmadı; Timurlu İmparatorluğu’nun yıkılmasının ardından birçok İranlı âlim eserlerini Fatih'e ithaf ettiler. Fatih, hac dönüşünde (1473) İstanbul'a çekmek için Hace Ataullah Kirmânî̀yi 5000 eşrefi altın beraberinde Molla Abdurrahman Câmînin yanına gönderdi. Gelmesi halinde 100 bin eşrefi altın vereceği vaadinde de bulundu. Yine Celaleddin Devvânî, Risâle-i İsbâtü'l-vâcib adlı eserini 886/1481-82'de Fatih'in adına yazmıştı. Abdurrahman Câmî, Celaleddin Devvânî, Seyfüddin Ahmed Taftazânî, Mîr Cemalüddin Ataullah, II. Bayezid'in yıllık hediye gönderdiği âlimler arasındaydı. Osmanlı ve İran uleması arasındaki kadim dostluk ve gidiş-gelişler, Osmanlıya daha önceden göç etmiş olan İran ulemasının yüksek medreselerde müderrislik başta olmak üzere çeşitli önemli mevkilere getirilmiş olmaları, İran ulemasının, burayı tercih etmesinde etkin rol oynamıştı. Ayrıntılı bilgi için bkz., Tofigh Heidarizadeh, "Muhajerat-e Ulama-ye Iran be Impraturi-ye Osmanî", Majalle-ye Farhang, 20-21 (Tehran 1375/1997), s. 50, 57-58. 
ve şehzade lalalığı gibi önemli görevlere getirildiler. ${ }^{2}$ Bunlardan biri de büyük bir Osmanlı tarihi kaleme alan İdrîs-i Bidlîsî idi. Bu makalede, II. Bayezid'in himayesine girdikten sonra yaşadığı zorluklar muvacehesinde yeni bir hami arayışına giren İdrîs-i Bidlîsînnin, intisap konusunda Şah İsmail'e müracaatı ile ilgili bugüne kadar bilinmeyen mektubu değerlendirilecektir.

Şah İsmail'in ortaya çıkışından sonra Tebriz'deki Heşt Behişt Sarayı'ndan ayrılanlar arasında Sultan Yakub'un (1478-1490) saltanatı zamanından beri Akkoyunlu sultanlarının münşiliğini yapan, hem babası Hüsamüddin Ali hem de Tebriz'deki medreselerden aldığg eğitimle önemli bir kariyer elde etmiş olan henüz kırklı yaşlarındaki İdrîs-i Bidlîsî de bulunuyordu. ${ }^{3} 1502$ 'de ayrıldıktan sonra Tebriz ile İstanbul arasında süren uzun yolculuğu ve muhtelif yerlerdeki ikamet ve faaliyetlerinin ardından İstanbul'a geldiği 1503 sonu 1504 yılı başlarında II. Bayezid tarafından hoşça karşılanan Bidlîsî, gözde bir Acem bürokratı ve âlimi olarak kendisine Osmanlı sarayında bir konum ve hami buldu. Ardından çok geçmeden kendi isteği ve padişahın da tevafuku ${ }^{4}$ üzerine bir imparatorluk kültür projesi olan Farsça bir Osmanlı hanedan tarihi kaleme almaya başladı. ${ }^{5}$

1504 'te başlayıp 1506 yılının ortalarında tamamlayacağı Heşt Behişt i kaleme aldığı süre içinde, sarayda II. Bayezid'ten başka hamisi olmayan Bidlîsî, devrin şair ve ulemasını koruyup destekleyen veziriazam Hadım Ali Paşa, kazasker Müeyyedzâde Kadı Abdurrahman ve sair saray ekâbiri tarafından pek iyi gözle bakılmayan bir yabancı olarak kabul edildi. İran'dan yeni gelen bu Acem’in, aldığı eğitime güvenerek saray çevresindeki şair ve ulemadan daha kuvvetli bir kaleme ve dünya görüşüne sahip olduğu iddiasında bulunması, saray içinde iyi bir konum elde etme, padişaha daha yakın olma ve bunun neticesinde kendisine bağlı bir himaye zinciri yaratma mücadelesi onun hakkında olumsuz görüşlerin oluşmasına yol açtı. Hadım Ali Paşa ve Müeyyedzâde Abdurrahman Efendi'nin başını çektiği, ilmi yeterliliklerini ölçmek adına yaptıkları "imtihan"larla intisap bekleyenlerin seçimi konusunda padişah üzerinde bariz bir şekilde etkili ve aynı zamanda Şehzade

2 Heiderizadeh, "Muhajerat-e Ulama-ye Iran be Impraturi-ye Osmanî”, s. 50-51.

3 Tebriz'deki ulema göçünün ayrıntıları için bkz., Vural Genç, "Acem'den Rum'a": İdris-i Bidlišsınin Hayatı, Tarihçiliğgi ve Heşt Behişt in II. Bayezid Kısmı (1481-1512)” (doktora tezi), İstanbul Üniversitesi Sosyal Bilimler Enstitüsü, 2014, s. 116-130.

4 Feridun M. Emecen, "II. Bâyezîd'in Tarih Merakı Üzerine Bir Not: Fenarîzâde Alâeddîn Alînnin Anonim Osmanlı Tarihi Derlemesi”, Kitaplara Vakfedilen Bir Ömre Tuhfe: İsmail E. Erünsal'a Armăgan, haz. Hatice Aynur, Bilgin Aydın, Mustafa Birol Ülker, İstanbul 2014, s. 335.

5 Genç, “Acem'den Rum'a”, s. 314-334. 
Ahmed yanlısı olan bu hizip Bidlîsîyi kısa zamanda hedef tahtasına oturttu. ${ }^{6}$ Bidlîsînnin, eserini yazarken bile bu isimleri eleştirmesi hatta onlara karşı sert bir tavır takınması saray içinde önemli bir mevki elde etmeye dayanan ve üstünlük mücadelesi olarak değerlendirebileceğimiz bu çekişmenin Heşt Behişt in takdim edilmesinden önce başladığına işaret eder. ${ }^{7}$ Ayrıca daha Fatih zamanından beri saray ve çevresinde İran'ın yüksek saray kültürü ve köklü medrese geleneğinden gelen ilim ve sanat erbâbına karşı bir üstünlük sağlama ve yarışma eğiliminin olduğu bilinmektedir. ${ }^{8}$

Nitekim eserini bitirir bitirmez Bidlîsî karşıtı bu hizip, onu Heşt Behişt üzerinden acımasızca eleştirecek, kitabın İran şahlarını övdüğünü, birçok kaynaktan alıntılarla vücuda getirildiğini, üslubundaki aşırılıktan dolayı metnin anlaşılmaz olduğunu iddia ederek tek koruyucusu olan padişahın gözünden düşürülmesinde rol oynayacaktı. Hadım Ali Paşa’nın bir hami olarak himaye ettiği şairlerin ${ }^{9}$ olması ve Müeyyedzâde Kadı Abdurrahman'ın ise gerek yirmili yaşlarda gittiği İran’da Celalüddin Devvânînnin medresesinde aldığı eğitim gerekse İran'da bulunan eski medrese arkadaşların ${ }^{10}$ padişaha takdim edip onun mektubuyla İran'dan İstanbul'a çağırması saraydaki himaye ağlarını gösteren önemli örneklerdir. Padişaha daha yakın olmaya dayanan böyle bir rekabet ortamında Bidlîsînin de İranî dünyanın kültürel arka planına sahip birisi olarak sarayda kendisine ileride himaye ağı kuracak kadar önemli bir mevki bulma çabasının bu hizip tarafından hoş karşılanmayacağı açıktı.

Tüm bu gözden düşürme, itibarsızlaştırma ve uzaklaştırma faaliyetleri netice vermiş olmalı ki II. Bayezid, eserini bitirdiği takdirde vereceğini söylediği

6 Bidlîsî ile bu hizip arasındaki çekişmenin ayrıntıları için bkz. Genç, "Acem’den Rum'a”, s. $165-190$.

7 Genç, “Acem'den Rum'a”, s. 850-852, 876-879; ayrıca karşılaştırma için bkz. İdrîs-i Bidlîsî, Heşt Behişt, Nuruosmaniye, nr. 3209, vr. 606b, 613b.

8 Halil İnalcık, Şair ve Patron: Patrimonyal Devlet ve Sanat Üzerinde Sosyolojik Bir Inceleme, (Ankara: Doğu Batı Yayınları, 2003), s. 21.

9 Mevlana Nihânî, Hadım Ali Paşa’nın musahiplerinden olup, şiirlerinde Kızılbaşlık karşıtı Sünni bir dil kullanır. Bkz. Günay Kut, Heşt Bihişt: The Tezzkire by Sehî Beg, (Sources of Oriental Languages and Literatures 5), Şinasi Tekin-Gönül Alpay Tekin (ed.), (Harvard Üniversitesi Basımevi, 1978), s. 258-259.

10 Muzafferüddin Ali Şirazî, Kadı Abdurrahman’ın medrese arkadaşı idi. Muzafferüddin, Şah İsmail'in ortaya çıkışı ile İran'dan Osmanlı topraklarına göç edince Kadı Abdurrahman'ın tavsiyesi üzerine Sahn-1 Seman medreselerinde tedrise başlamıştı. Ayrıntılı bilgi için bkz. Heidarizadeh, "Muhajerat-e Ulama-e Iran be Impraturi-e Osmanî”, s.64. 
ve Bidlîsînin "malî ve mevki yönden vaatler" olarak tanımladığı sözlerini yerine getirmekten vazgeçti. Bunun üzerine eseri tamamlamayıp dibacesiz ve hatimesiz bir şekilde bırakan Bidlîsî, her ne kadar bundan sonrasında padişahın bazı küçük inamlarını almış olsa da resmen onun himayesinden çıkmış bulunuyordu. 1506 ile 1511 arasında yaklaşık olarak beş yıl boyunca bu hizbin hedefi haline gelen ve sıkıntılı günler geçiren Bidlîsî son çareyi İstanbul'dan ayrılmakta buldu. Esas niyeti hiç kuşkusuz kendisine yeni bir hami bulmaktı ve bunun için epeydir bir hazırlık içerisindeydi.

Bidlîsînnin, en son olarak dile getirdiği hacca gitme niyetinden önce 1506 ile 1511 tarihleri arasında bahsettiğimiz hizbin hedefi haline geldiği bu süre boyunca İran'a dönmek ve Şah İsmail'e intisap etmek gibi bir arzu taşıdığı, onun ardında bıraktığı ve burada bahsedilecek olan yazışmaları okunduğunda rahatlıkla ileri sürülebilir. ${ }^{11}$ Hatta daha saray çevresinde iken tahminen $1510-11$ yıllarında içinde taşıdığı Diyarbekir'e gitme arzusu ve bunun için padişahtan izin istemesi bu fikrin o dönemlerde ortaya çıktığına işaret eder. Diyarbekir o tarihlerde Safevî toprağı idi ve Şah İsmail'in en güvenilir beylerinden Ustaclu Muhammed Han tarafından idare ediliyordu. Bidlîsî uzun zamandır kafasında kurgulamaya çalıştığı Şah İsmail'e intisap etme teşebbüsünde burayı ilk durak olarak kullanmak istemiş olabilir. ${ }^{12}$ Üstelik tam da bu esnada İran tarafındaki dostlarıyla bu konuda yazışmaya başlaması onun düşüncelerini açığa çıkarır. Niyeti, buradan gelecek olan olumlu bir cevap üzerine Diyarbekir'e hareket ederek, oradan da tekrar Tebriz'e geçmekti. Ancak anlaşılan bu isteğine pek sıcak bakılmadı. İran tarafı ile olan mektuplaşmalar, onun saray çevresiyle olan ilişkilerini, içinde bulunduğu ruh halini ve geleceğe dair ne yapmak istediğini ortaya koyan önemli detaylar vermektedir. ${ }^{13}$ Bu cümleden Tebriz'de iken Sultan Yakub'un meclislerine beraberce katıldıkları eski dostu Şeyhülislam Emir Abdülvehhab’a yazdığı bir mektup onun 1512 tarihinden çok önce henüz İstanbul'da iken İran tarafıyla bağlantı halinde olduğunu ortaya koyar. ${ }^{14}$ Şeyhülislam Emir Abdülvehhâb’a yazdığı mektup daha

11 Şah İsmail'e yazdığı kaside/mektubunda içinde sürekli şaha gitmek gibi bir arzu taşıdığını belirtmesi bu niyetini açıklar. Bkz. İdrîs-i Bidlîsî, Cevâb-ı Risâle-i Şâhîye (Kasâid Münşeât ve Mürâselât), Süleymaniye Ktp. Esad Efendi, nr. 1888/3, vr. 146a.

12 Bidlîsînnin Diyarbekir'e dönmek için padişahtan izin istemesi için bkz. Genç, “Acem’den Rum'a”, s. 197-200.

13 Bidlîsîn nin İranlı dostları ile olan yazışmaların ayrıntıları için bkz. Genç, “Acem’den Rum'a”, s. 180-81

14 Muhyî-i Gülşenî, Menâkıb-ı İbrahim Gülşenı̂, haz. Tahsin Yazıcı, (Ankara: TTK Yayınları, 1982), s. 104. 
önce İran tarafıyla olan yazışma ve haberleşmenin akışına ışık tutması bakımından da oldukça önemlidir. Bir Akkoyunlu seçkini olan Şeyhülislam Emir Abdülvehhâb Şah İsmail'in ortaya çııışıyla dengelerin değişmesinden dolayı Tebriżi terk etmek durumunda kalıp Herat’a giderek Sultan Hüseyin Baykara’nın himayesine girmiş, Hüseyin Baykara'nın 1506 yılında ölümünden sonra Şah İsmail ile yazışarak Tebriz'e davet edilmişti. ${ }^{15}$ Dolayısıyla Bidlîsî ile Emir Abdülvehhâb arasındaki bu yazışma Emir Abdülvehhâb'in Tebriz'e geldiği tarih olan 1506 yılı sonrasına aitti ve Emir Abdülvehhâb'ın gönderdiği mektuba Bidlîsî tarafından verilen cevap niteliğini taşıyordu. Bu yazışmalar Diyarbekir'e yerleşme fikrini ortaya attı̆̆ bir zamana denk gelmekteydi. Bir taraftan sultandan Diyarbekir'e gitmek için izin isterken diğer taraftan bu noktada bir bağlantı kurmaya çalıştı. Belli ki Bidlîsî bu geri dönüş için kadim dostu Emir Abdülvehhâb’ aracı seçmişti. Aynı kaderi paylaştığı Emir Abdülvehhâb'in Şah'a intisap etmesi Bidlîsî̀yi bu konuda cesaretlendirmiş olabilir. İran tarafından dört gözle beklediği mektubu sevinçle aldığını belirten Bidlîsî şöyle devam ediyordu:

Beğenilmiş sözcüklerle dolu bu kutlu haberleri duyar duymaz, mülazemeti arzulayan gözlerimle onu öptüm. O hakiki eşikten ayrı düştüğüm, meleklerin sığındığı o eşiğin mülazımlarını görmekten uzak kaldığım bu muhaceret yıllarında zayi ettiğim ömre nasıl da hayıflanıyorum. Fakirin, muhaceretinin başlangıcından bu zamana kadar yaşadıkları, en değerli zamanının zayi olmasına ve meclis mülazımlarının başının ağrıtılmasına neden olmuştu. Zaruri olan şeyleri bildirmede sadece o taraftaki bazı aziz dost ve kardeşlerin mektup ve yazışmalarını okumakla yetindim. Lütuf ve merhametinizden beklediğim şey, din ve devlet erbabıyla, mülk ve millet işlerinin kefilleriyle yüz yüze görüşerek ya da yazışarak bu fakirin gerçek isteğini idrak ettirme ve ihlâsı yolundaki çabalarını, üç yıl boyunca bu fakirin mektuplarına cevap vermede gösterilen ciddiyetsizlik ve lakayıtlığı yüce hatırlara yansıtmanızdır. Fakirlerin nefsî ve malî olarak kendilerini attıkları tehlikeli girişimlere rağmen bu süre boyunca o taraftan hiçbir şekilde dikkatleri çekmedi. Bu mektubunuzda o taraflara olan ilgi babındaki şeyler itaat kulağıyla dinlendi. Mektup, o yüce zatın sahip olduğu gizli şefkat ve sevecenliği kendisinde barındırıyordu. Çünkü diğer hazerata hizmet etmek düşünülmemişti. Şimdi kader olsa gerek istek ve irade dışında ortaya çıkan bazı şeyler geciktirme parmaklarını hızlı hareket eden bu eteğe doladı. Gaddar olan zaman da bu arada arzu gözü ve maksat yanağını fitne tozlarına buladı. Umarım o yüce zatın yüce himmetiyle ve

15 Rijâl-e Kitab-e Habib al-Siyar, haz. Abd al-Husayn Navai, (Tehran: Anjuman-e Asar va Mafakhir-e Farhangi, 1379), s. 277; Esnad va Mukatebat-e Tarikhi-e Iran az Timur ta Shah Ismail Hamrah ba Yaddashtha-ye Tafsili, haz. Abd al-Husayn Navai, (Tehran: Muassasa-ye Mutalaat-e Islami, 1370), s. 231-232. 
dua nefeslerinin üfürülmesiyle yardım getirecek olan bulutların üzerindeki perde kalkar ve ayrılık sona erer. Oraya selâmetle girin hoş sadası gayb evinden âşıların can kulağına ulaşı1 ${ }^{16}$.

O açıkça Osmanlı sarayında iken Şah tarafından himaye ve mülazemet beklediği 1511 yılından önceki üç yıl boyunca yani 1508-1511 arasında çeşitli vesilelerle Tebriz sarayındaki bazı devlet büyükleri ile yazıştığını, o taraftan sürekli haberler aldığını ancak iletişim kopukluğunun bazı sorunlar yarattığını itiraf ediyordu. Bir kez daha "meleklerin sığınağı, hakiki eşik" dediği Şah İsmail'in sarayından ayrıldığının altını çizerek aşağıda bahsedileceği üzere Tebriz'de Şah’tan gördügü kısa süreli himayeye gönderme yapıyor, üstü kapalı olarak Bayezid'in himayesinde geçirdiği zamanın ise boşa geçtiğini vurguluyordu. Hatta bu yazışmaları hayatını tehlikeye atarak gerçekleştirdiğini söylüyordu. Zira bu irtibat Osmanlı sarayında ifşa olduğu takdirde kendisinin de sonunu hazırlayabilirdi. Onun için son derece dikkatli yapmalıydı. Bu denemelerden sonuncusu olarak kadim dostu Emir Abdülvvehâb ile yaptığı yazışma ona gerekli ortamı sağlamış gözükmektedir. Bidlîsî, Abdülvehhâb’ Şah İsmail ile kendi arasında aracı tayin etmişti. Abdülvehhâb' ın kendisi de Herat'ta iken böyle bir aracılıkla Şah İsmail ile irtibata geçmişti. Şimdi Bidlîsî için harekete geçecekti. Abdülvehhâb'in Şah ile görüşmesinin ardından güvenilir adamları aracıllğıyla gönderdiği mektubu yukarıdaki cevabi mektuptan da anlaşılacağı üzere Bidlîsînin intisabı konusunda Heşt Behişt Sarayı'na hâkim olan olumlu atmosferi yansıtıyordu. Tebriz sarayı ile ilgili gerekli irtibat sağlanmıştı. Şimdi geriye tek bir mesele kalıyordu; bir yolunu bulup İstanbul'dan çıkmak. Ancak bunun için biraz daha beklemesi gerekecekti. Zira mektubunda "gaddar olan zamanın çıkardığı fitne" olarak belirttiği bazı olaylar -ki bunlar kuşkusuz 1511 yılına ait Şahkulu hareketi ve bunun getirdiği şehzade mücadeleleri idi- payitahtta bir kaos yaratmış olduğu için şimdilik çıkışını engellemekteydi. Bu detay, mektuplaşmanın tarihi hakkında fikir vermektedir. Buna göre Bidlîsînnin, Emir Abdülvehhâb’a yazdığı cevabi mektubun tarihi 1511 yılı ortaları olmalıdır ${ }^{17}$.

Üstelik İran'dan ayrılma arifesinde Şah İsmail'e yazdığı öne sürülen bir kasidesinde de Şah'ın davetini açıkça reddetmemiş, aksine bu davete Şah tarafindan kendisine verilecek bir görevi büyük bir iştiyakla kabul edecek bir cevabî kasideyle karşılık vermişti. Kasidesinde Bidlîsî, baba ve dedesinden bu yana Şah’ın

16 İdrîs-i Bidlîsî̀, Murâsele-i Cevâb-i Mektûb-ı Seyyidüs-SâdâtSSeyhulislam Emîr Abdülvehbâb (Kasâid Münşeât ve Mürâselât), Süleymaniye Ktp. Esad Efendi, nr. 1888, vr. 148b-149b. 17 Genç, “Acem'den Rum'a”, s. 213-215. 
hanedanının kulları olduğunu, baba ve dedesinin Şah'ın baba ve dedelerinin hizmetinde bulunduğunu, babası Hüsamüddin Ali'nin, Şah'ın dedesinin [Şeyh Cüneyd] şagirtlerinden olduğunu, zâhirî ilimleri ve bâtını ondan öğrendiğini ve onun sayesinde aydınlandığını ifade ederek açık bir kapı bırakacaktı. ${ }^{18}$

Kısacası içinde bulunduğu şartlar İran’a dönmesi için oldukça müsait görünüyordu. II. Bayezid'in Bidlîsînnin İran'a dönme ihtimalinin olduğunu tahmin etmesi ve bundan dolayı onun İstanbul'dan çıkışına izin vermemiş olması kuvvetle muhtemeldir. İstanbul'dan ayrılma konusunda giriştiği ilk teşebbüsün ardından Diyarbekir'e dönme konusunda almış olduğunu düşündüğümüz olumsuz cevap onu kimsenin dikkatini çekmeyecek bir başka yer olan Mekke'ye gitmeye yönlendirdi. Aslında hamisini kaybeden ve çeşitli nedenlerde bulunduğu yerden uzaklaşmak isteyen birisi olarak Bidlîsînnin Mekke'ye gitme talebi mazul, nekbete uğramış ulemanın da sıklıkla başvurduğu bir bahane sayılırdı. Onun gerçek niyetinin muhtemelen farkında olan padişah ve karşıt hizip bu isteğini geri çevirdi. Hacca gitme isteğini her defasında yenileyen ve düşmanlarının yoğun baskısı karşısında bir türlü alamayan Bidlîsî, nihayet 1511'de padişahın, oğlu Şehzade Selim meselesi ile uğraşması sırasında Edirne'de onun huzuruna çıkarak bir kez daha hac için izin istedi. Sultanın bu meşgul halinden istifade ederek ona yalvardı. Hatta kendi ifadesiyle "yüzlerce hileye başvurarak" bu isteğini yineledi. Bu kargaşa ortamında nihayet hac iznini koparmayı başardı. 1511 yazında adeta ailesini de geri dönme teminatı gibi İstanbul'da bırakarak oradan ayrıldı. ${ }^{19}$

İstanbul'dan ayrıldıktan sonra onun uğrayacağı ilk durak kadim mürşitlerinden biri olan ve kendisi gibi Tebriz’den ayrılan İbrahim Gülşenînin bulunduğu Kahire olacaktı. Bidlîsî kendisini hoşça karşılayan ve oldukça fazla ilgi gösteren hatta kendisine bir kitap dahi takdim ettiği Memluk sultanı Kanısav Gurîyi pekâlâ yeni bir hami olarak görebilirdi. Üstelik Tebriz'de iken neredeyse bütün zamanını mürşid-mürid ilişkisi çerçevesinde birlikte geçirdiği İbrahim Gülşenînin de burada oluşu Bidlîsî için avantaj sayılabilirdi. Ancak yukarıda da bahsedildiği gibi daha İstanbul'da iken Tebriz'e geri dönmek gibi bir niyet taşıdığından ve başka hesaplar yaptı̆̆ından böyle bir düşünce içerisine girmeyecek, Kanısav Guri’nin,

18 Bu kasideden sadece Şeref Han Bidlîsî bahseder. Bkz. Şeref Han Bidlîsî, Şerefnâme: Tarikh-e Mufassal-e Kurdistan, haz. V. Veliaminof Zernof, (Tehran: Intisharat-e Esatir, 1377), s. 343-344.

19 Genç, “Acem’den Rum'a”, s. 941-943; karşılaştırma için bkz. İdrîs-i Bidlîsî, Heşt Behişt, Nuruosmaniye, nr. 3209, vr. 633b; ayrıca Bidlîsînnin saray çevresinde karşılaştığı bu zorluklar ile Mekke'ye gidene kadarki yaşamına dair ayrıntılı bilgi için bkz. Genç, “Acem'den Rum'a”, s. 165-217. 
güzergâhı üzerinde kendisine yardımcı olunması yönünde verdiği bir beratla bir müddet kaldığı Kahire'den ayrılarak Mekke’ye yönelecekti.

Mekke'ye gelen ve hac vazifesini yerine getiren Bidlîsî, artık İstanbul'dan beri kafasında tasarladığı Tebriz'e dönüp Şah İsmail'in himayesine girme fikrini uygulamaya geçirebilirdi. Nitekim hac görevini yerine getirdikten sonra Mekke'de kalmaya devam etmesi onun bu yönlü bir temayüle sahip olduğuna pekâlâ işaret eder. Kendisinin de belirttiği gibi buradayken Hint ve sair ülkelerden gelen hacılarla görüşüyor, onlarla çeşitli meclislerde çeşitli konular üzerine sohbetler yapıyordu. ${ }^{20}$ Muhtemelen İran'dan gelen hacı veyahut tüccarlarla da konuşma firsatı yakalıyor ve sürekli hasretle bahsettiği İran'ın durumuna ve Şah İsmail'in faaliyetlerine dair haberler alıyordu. Uzun süren bir bekleyişin ardından daha İstanbul'da göz hapsinde iken kafasında kurguladığı ve bunun için İran tarafıyla irtibat halinde olduğu ilişkiyi hayata geçirmek için harekete geçmeye karar verdi.

Bidlîsîye ait mevcut külliyat arasında tarafımızca tespit edilen biri kısa biri oldukça uzun şikâyetname/tazarru'nâme formu taşıyan iki adet kaside/mektup, onun Mekke'de iken 1512-1513 yılları içerisinde Şah İsmail ile bir bağlantı kurduğunu açık bir şekilde gösterir. İstanbul'daki yazışmaların devamı niteliği taşıyan bu mektuplardan ilki, Şah tarafından kabul edilme talebinde bulunduğu kısa bir kasidedir. İkincisi ise Şah İsmail tarafından bir haberci vasıtasıyla gönderilen mektuba verdiği cevaptır. Bu ikincisi de manzum olarak kaleme alınmıştır ve Şah İsmail'den kendisine gelen mektubun muhtevasına da sşık tutar. ${ }^{21}$

Şah İsmail'e yazdığı şikâyetnâme türündeki kaside, aralarında gerçekleşecek olan yazışmanın muhtemelen ilk halkasıdır. Hayal kırıklığı ve pişmanlık dolu duygularla kaleme aldığı kasidesinde Şah’a şöyle hitap ediyordu:

Yârin kapısından uzak görmediğim bela, çekmediğim sstırap kalmadı. Gönlüm perişan, gözlerim kan ağlamaklı. Başım senin kapının toprağından ayrıldı, sanki canım tenimden ayrılmıştı. Eğer bir daha senin kapından ayrılırsam başımı gövdemden ayır! İdrîs sen canı canana son anda yetiştir! İran’ın Behrâm gibi olan serverinin kapısına iltica et ve şiir ve nesirler kaleme alarak onun duagûyı ol! Ey baht onun cömertlik çığlığıyla uykundan uyan! Şah’ın sancağı her daim muzaffer olsun! Allah'ın yardımı ondan uzakta olmasın! ${ }^{22}$

20 Bidliŝî, Mekke'de iken II. Bayezid'e yazdığı mektubunda görüşüp sohbet ettiği kişilerden ve onların Heşt Behişt nüshalarını temin ederek Hint ve sair memleketlere götürmek istediklerinden bahseder. Bkz. Topkapı Sarayı Müzesi Arşivi (TSMA), E. 5675.

21 İdrîs-i Bidlîsî, Cevâb-ı Risâle-i Şâhî̀ye, vr. 144a-147a.

22 İdrîs-i Bidlîsî, Murâsele ila ba'zı 'uzamâ el-'Acem (Kasâid Münşeât ve Mürâselât), Esad Efendi, nr. 1888/3, vr. 148a. 
Aslında Şah tarafından nasıl bir tepkiyle karşılaşacağını bilemediğinden İranlı hacılar veya tüccarlarla memleketi Tebriz’e dönmek yerine, biraz temkinli davranarak kaside gönderip zemini yoklamayı hedeflemişti ve İstanbul'da iken başladığı irtibatı sürdürüyordu. Bidlîsînin, Şah İsmail'e yazdığı, bu yazışma halkasının sonuncusu olan uzun kaside/mektup, Şah'tan ilk olarak gelen cevabî mektuptan bahsederek bu yazışmaların ikincisinin yani Bidlîsînin ilk gönderdiği kasideye gelen cevabın varlı̆̆ını resmen açıklar. Bidlîsînnin gelen mektuba verdiği cevap Şah'tan gelen mektubun içeriğine de ışık tutmaktadır. Özel bir haberci ile hediyeler beraberinde gönderdiği mektubunda hem Şah'ın hem de devlet erkânının kendisine duyduğu muhabbet ve bulundukları lütuf ve inayetten bahseder. Şah'ın adının ve tuğrasının yer aldığını söylediği bu mektubun oldukça uzun olduğunu belirtir. ${ }^{23}$

Elimizdeki kaside/mektuptan anlaşıldığı kadarıyla Bidlîsînin Mekke'de ikamet ettiğini haber alan Şah İsmail, bu haber üzerine yazdığı mektubu ve hediyelerini özel bir haberci vasıtasıyla Mekke’ye göndermişti. Şah İsmail mektubunda, Bidlîsînnin Tebriz’e geri dönmesini istiyor, onu hizmetine kabul ettiğini belirtiyordu. İki taraf arasındaki yazışmaların son halkası niteliğindeki bu cevabî kaside/mektup aynı zamanda Bidlîsînin zihin dünyasındaki değişikleri gözler önüne seren önemli bir belgedir. Bütün bu mektuplaşmalar ve sağlanan irtibatlar Bidlîsînnin Mekke'de kaldığı ortalama bir buçuk yıllık süre (1512-1513) zarfında gerçekleşmişti.

Şah İsmail'e övgülerle başladığı, methiyelerle dolu olan söz konusu mektubunda Bidlîsî, onu Hz. Ali gibi civanmert, onun sıfatlarına sahip, Zülfikar kılıcıyla Ehl-i Beyt'in hakkını Mervan'dan alan, sınırsız cömertliğe sahip bir kişi olarak niteler. Adına hutbe okuttuğundan ve para bastırdığından bahsederken "İslam'ın minberi Şah'ın adına okunan hutbe ile süslendi” ifadeleriyle adeta onu İslam'ın koruyucusu ve yegâne temsilcisi olarak görerek onun hükümdarlığının meşru bir zemine dayandığı mesajını verir. ${ }^{24}$ "Bu zamanda senden başka bir Şah var mıdır ki atının otu ve arpası Tiflis'ten suyu ise Umman'dan gelsin, senin azimet atın Hind ülkesinden kalkınca ikinci adımını Errân ülkesine koyar" ${ }^{25}$ satırlarıyla adeta Şah'ın egemenlik sahasını kuzeyden güneye, doğudan batıya resmederek güçlü bir şah profili çizer. Daha sonra Şah’ın, Özbek hanı Muhammed Şeybânîye karşı kazandığı galibiyetten bahsederek bir fetih müjdesi olarak gelen Şeybânînnin kesik başının Sultan Bayezid'i dehşete düşürdüğü, Şah'ın heybetinin Rum'da zelzele etkisi yaratıp Kayserin [II. Bayezid] kasrının yıkılıp, Kisranın [Şah İsmail] kubbesinin bina

23 İdrîs-i Bidlîsî, Cevâb-ı Risâle-i Şâhîye, vr. 146a.

24 İdrîs-i Bidlîsî, Cevâb-ı Risâle-i Şâhîye, vr. 144a, 145a.

25 İdrîs-i Bidlîsî, Cevâb-ı Risâle-i Şâhîye, vr. 145a. 
edildiği ifadeleriyle Şah İsmail'i över. ${ }^{26}$ Bütün İran ve Maveraünnehir'in tacının sahibi olduğunu, kılıcı Mısır'a yetişecek olsa orayı dahi alacağını, Hind Racası ve Rum Sultanı da dâhil doğudan batıya bütün sultanların taçlarını alması gerektiğini dile getirerek tıpkı bir zamanlar Osmanlı padişahlarına biçtiği rolü şimdi Şah İsmail'e biçer. ${ }^{27}$

Mektubunun sonlarına doğru İran'dan ayrılıp Osmanlıya sığınmaktan, Şah'ın zamanında onun dışında başka birilerine (Osmanlı padişahları) methiye yazmaktan duyduğu pişmanlığı ifade ederek Şah'tan af talep eder, ömrünün kalan kısmını Şah adına kitaplar telif etmekle geçirmeyi ister ve en başından beri içinde sürekli Şah’a gitmek gibi bir düşüncenin olduğunu "yüzünün daima Şah’ın kapısının kıblesinde olduğunu” yineler. ${ }^{28}$ Bidlîsî, baştan beri İran'dan ayrılmakla büyük bir hata ettiğini ve bundan pişmanlık duyduğunu dile getirirken Osmanlı sarayında yaşadıklarını birkaç satırda özetlemektedir. Kendisini Şah'ın dergâhının kadim bir kulu olarak görerek ondan ayrılıp karanlık çöllere düşmenin reva olmadığını, bu ayrılık süresi içerisinde "şeytan siretliler" ile uğraşmak zorunda kaldığını, "cahil ve dalkavukların esiri” olduğunu söyleyerek Hadım Ali Paşa ve Müeyyedzade’nin başını çektiği hizipten gördüğü zulmü adeta Şah'a şikâyet eder. ${ }^{29}$ Kendisini hapis olduğu kafesten kurtulan bir kuşa benzeten Bidlîsî, aslında bu satırlarla İstanbul'da yaşadığı sıkıntılı süreci özetlemektedir. Bir kurtarıcı gözüyle baktığı Şah'tan İstanbul'da bıraktı̆̆ı ailesi ve çocuklarının kurtulması için yardım talep eder. Bunun ardından Şah'ın huzuruna ilim vasfı ve âlim sıfatı taşıyan birisi olarak çıkmak istediğini dile getirir. ${ }^{30}$

Mektupta Şah İsmail etrafında onun lehine ve Osmanlı aleyhine sürdürülen siyasal polemikler ve Şiî eksenli meşruiyet tartışmaları kendisini hissettirir. Hemen belirtilmelidir ki sıradan bir mektup olmanın çok ötesinde, siyasi ve politik bir veçhe taşıyan metinde Bidlîsî, daha Şah'a intisap etmeden önce onun politik egemenlik sahasını çizmiş ve iktidarının meşruiyetini Şiî referanslarla temellendirmiş, oluşturduğu emperyal kurgu içerisinde doğudan batıya, kuzeyden güneye geniş bir coğrafyanın mutlak sahibi şeklinde takdim ederek İslamî ve İranî referansları şahsında toplayan bir şah profili yaratmıştı. İstanbul'u alması, "Rum kayserinin tahtına ve tacına" sahip olması için adeta onu teşvik etmişti.

26 İdrîs-i Bidlîsî, Cevâb-ı Risâle-i Şâhîye, vr. 145 b.

27 İdrîs-i Bidlîsî, Cevâb-ı Risâle-i Şâhîye, vr. 145b.

28 İdrîs-i Bidlîsî, Cevâb-ı Risâle-i Şâhîye, vr. 146a, 147a.

29 İdrîs-i Bidlîsî, Cevâb-ı Risâle-i Şâhîye, vr. 144b.

30 İdrîs-i Bidlîsî, Cevâb-ı Risâle-i Şâhîye, vr. 146b-147a. 
Şah İsmail'i İstanbul'daki tahtın yeni sahibi olarak gören Bidlîsî̀nin bu düşüncesi "İstanbul şehrinde ol sahib-i devlet, tâc-1 devlet ile salınmalıdır" satırlarıyla Şah’ı İstanbul tahtına oturtan 16. yüzyılın Kızılbaş şairi Pir Sultan Abdal'ın düşünce ve kurgusundan farklı değildir.

Bidlîsînnin sadece bu satırlarını okuyan birisi onun mutaassıp bir Şiî olduğu hissine kapılabilir. Şiî eksenli çizdiği bu emperyal profilde o, Şah İsmail’i İslam davasının yegâne sahibi, eşiği Kâbe'ye denk olan, Ehl-i Beyt' in haklarının koruyucusu, Çingiz ve Moğol ordularını mağlup eden, heybetiyle Rum'da ve Mısır'da zelzele yaratan, II. Bayezid'in tacının yeni sahibi ve Hz. Ali'nin temsilcisi (Haydar-1 Sânî) olarak resmediyordu. Satırlarından anlaşıldığı kadarıyla Bidlîsî, Şah İsmail'in himayesine giren ve zamanla Şiîliğe entegre olan tüm diğer Akkoyunlu Sünni seçkinleri gibi kendisini Şiîliğe entegre olmuş birisi olarak yansıttı -ki mektubu bu konuda hiçte zorlanmayacağını gösterir- ya da en azından Şah İsmail tarafından bu şekilde algılanması için çok çaba sarf etti. ${ }^{31}$

Bidlîsî tarafından Şah İsmail’e gönderilen kaside/mektupların bir diğer önemli özelliği de 1502 yılında Tebriz'den ayrılmasına bir nebze de olsa ışık tutacak ipuçları barındırıyor olmalarıdır. "Şah'ın dergâhının kadim bir kulu olarak ondan ayrılıp karanlık çöllere düşmenin reva olmadığını" dile getirerek aralarında ciddi bir sorun yaşanmadığını, hatta bir müddet onun hizmetinde kalmış olduğunu açıkça itiraf eder. En azından Tebriz'den ayrılmasına neden olacak Şah karşıtı dinsel bir tartışmaya veya muhalefete girmediğinin de önemli bir kanıtı olabilir. Gerçekten kendisine isnat edilen bu tür bir davranış içerisinde bulunarak Şah İsmail'e ve mezhebine karşı böyle sert bir tutum takınmış olsaydı ${ }^{32}$, Mekke'de iken onun sarayına tekrar intisap etmeyi aklından bile geçirmezdi. Dolayısıyla Tebriz'e geri dönmek ve Şah'ın himayesine girmek isteyişi onun en azından Tebriz'den ciddi bir mesele yüzünden ayrılmadığına işaret edebilir. ${ }^{33}$

31 Genç, “Acemiden Rum'a”, s. 366.

32 Akkoyunlu kronik yazarı ve Bidlîsînnin de Heşt Behişt Sarayı'ndaki yakın çevresinden Fazlullah ibn Ruzbihan bunun en açık örneğidir. Ruzbihan'ın hem kroniğinde hem de çeşitli yazışmalarında Şah İsmail'in dedesi Şeyh Cüneyd ve babası Şeyh Haydar ile onların inançları hakkında kullandığı aşağılayıcı ifadeler onun 1501'den sonra İran'dan kaçıp Maveraünnehr tarafına, Özbek hanına sı̆̆ınmasına neden olmuştur. Mutaassıp bir Sünni olan müellif, Alam Aray-ı Amini adlı eserinde Şah İsmail'in babası Şeyh Haydar ve takipçileri için "gosâleparastân-ı Rum” (Rum'un buzağıya tapanları) ifadesini kullanmış, Safevî hanedanı için çok sivri bir dil geliştirmişti. Bkz. Fazlullah ibn Ruzbihan, Tarikh-i Alam Aray-i Amini, haz. Muhammed Akbar Ashiq, (Tehran: Anjuman-e Asar va Mafakhir-e Farhangi, 2003), s. 252.

33 Genç, “Acem'den Rum'a”, s. 239-241. 
Bidlîsînnin Şah İsmail'i hami olarak seçmesi ve bunun gerçekleşmesi için çaba sarf etmesi yaşadığı dönemin siyasal konjonktörünün getirdiği sıkıntılardan dolayı yeni bir hami bulabilme arayışı olarak okunmalı ve patronaj ilişkisi çerçevesinde değerlendirilmelidir. Bununla beraber bu kaside/mektubun içeriğinin gösterdiği gibi pekâlâ bir taraf değiştirme şeklinde de anlaşlabilir. Tebriz'den İstanbul'a gelişi ile tekrar Tebriz'e gitmek isteyişi aynı saikler çerçevesinde okunabilir. Hem Osman$l_{1}$ hem de İran coğrafyasında yeni hamiler ve zengin patronlar bulmak amacıyla mobilize olan, hamisinden beklediği ilgiyi göremediği için bulundukları yerden ayrılan ilim ve sanat erbabının sayısı oldukça fazlaydı. Bu bilgin ve sanatkârların yegâne refah kaynakları, zengin hamiler olduğu için intisapta esas olan hami ile kulun ortak dünya görüşüne sahip olması değil, haminin zengin ve cömert, himaye görenin ise hüner sahibi olmasıydı. Nitekim önce Sünni daha sonra bir Şiî hanedanın himayesine giren, kendisi Sünni olup Şiî hanedandan ya da kendisi Şiî olup Sünni hanedanlardan himaye gören bilgin ve sanatkârlar mevcuttu. Buna örnek olarak iki Sünni hanedandan (Akkoyunlu-Osmanlı) himaye gören Bidlîsî şimdilerde, Şah İsmail'in himayesine girmeye hazırdı. Aynı durum Kanunî Sultan Süleyman ile Şiî olan Fuzulî arasındaki hami-kul ilişkisi için de geçerliydi.

Sonuç olarak Şah İsmail'in parlayan yıldızı, 1512'ye gelindiğinde doğuda Kandahar-Belh, batıda Bağdat-Basra hattı içinde büyük bir imparatorluk vücuda getirmesi hatta yoğun bir takipçi kitlesine sahip olduğu Anadolu'da, politik egemenlik sahasını Fırat'a kadar uzatması, gayri memnun konumdaki Bidlîsîyi kendisine doğru çekiyordu. 1511-1512 yıllarında Osmanl1-İ́ran arasındaki bu güç dengesi terazisinin İran kefesi daha ağır basmaya başlamıştı. 1511 yılından itibaren Şahkulu isyanının sarayda bıraktığı izler ve hemen akabinde başlayan şehzadelerin mücadelesi II. Bayezid'in elini zayıflatmış, doğudan gelen bu ciddi tehdit karşısında çaresiz kalan bir sultan imajını ortaya çıkarmıştı. ${ }^{34}$ Bu siyasi konjonktör içerisinde bütün olan biteni iyi gözlemleyen Bidlîsîn nin Şah İsmail'den gelen mektuba verdiği cevabında Şah'ın doğudaki amansız rakipleri olan Özbekler karşısında aldığı galibiyetin (Merv 1510), Muhammed Şeybanîye ait olup gönderdiği kesik başın İstanbul'da saraydaki yansımaları İran'a, Şah İsmail'in hizmetine dönmeyi bu dönemden itibaren düşündüğünü hatıra getirir. 1506 yılından 1511 yılına kadar İstanbul'da kendi tabiriyle "mahpus" kaldığı bu dönemde Bidlîsî, hem sultan hem de saray çevresi tarafından dışlandığı, "adeta bir tutsak" gibi hiçbir yere gitmesine izin verilmediği bir ortamda Şah İsmail'in doğrudan ve dolaylı olarak

34 Bidlîsînnin İstanbul'daki son yıllarında sarayın içinde bulunduğu atmosfer için bkz. Feridun M. Emecen, Yavuz Sultan Selim, (İstanbul: Yitik Hazine Yayınları, 2010), s. $45-57$. 
üç büyük galibiyetini işitmişti: Bunlardan ilki, Şah'ın Osmanlı topraklarından geçerek 1508 yılında Alaüddevle'yi cezalandırması, ikincisi Özbek hanı Şeybanî Han’a karşı aldığı galibiyet (1510) ve onun başını keserek gözdağı olsun diye II. Bayezid'e göndermesi, üçüncü olarak doğrudan olmasa bile Şahkulu hareketi (1511) vasıtayla Şah'ın güçlenen yenilmezlik imajı. ${ }^{35}$

Tüm bu saikler dikkate alındığında Bidlîsînin neden Şah İsmail'in sarayına; kendisinin de bir zamanlar bulunduğu Heşt Behişt Sarayína geri dönmek istediği daha rahat anlaşılacaktır. Bidlîsînnin gönderdiği cevabî kaside/mektubun Şah İsmail'e ulaşıp ulaşmadığını bilemiyoruz. Ancak kendisinin hemen harekete geçmeyişi muhtemelen Şah'tan yeni bir mektup beklemesiyle açıklanabilir. Tam da bu sırada Şah İsmail ile İdrîs-i Bidlîsîn nin müstakbel buluşmasını, Bidlîsînnin İran’a dönmesini imkânsız hale getirecek bir hadise yaşandı; İstanbul'daki taht değişikliği ile II. Bayezid'in yerine oğlu I. Selim'in tahta çıktı. Bidlîsî bu taht değişikliğini İran'a dönme arifesinde iken Mekke sokaklarındaki tellallardan öğrendi. ${ }^{36}$ Tahta geçişinden kısa bir süre sonra yeni padişah Selim bir mektup göndererek onu Mekke'den İstanbul'a çağıracaktı. Onu Mekke'den geri çağırmasında iki faktör etkili olmuş gözükmektedir: Birincisi daha öncesinde çeşitli vesilelerle kendi adına eserler ve kasideler kaleme alan yakından tanıdığı bir âlim ve bürokratı tekrar himaye etmek, ikinci olarak da yapacağı İran sefer öncesinde o bölgeyi iyi bilen birisi olarak onun deneyimlerinden faydalanmak. Şah'tan ve Sultan'dan bir biri ardına gelen bu davetler ikincisinin lehine sonuçlandı. Selim, Mekke’ye gönderdiği elçi ve mektubun ardından Bidlîsînin İstanbul'a dönmesini sağladı. İstanbul'daki bu gelişme ve Bidlîsînnin geri dönmek isteyişi Şah İsmail ile Bidlîsî arasındaki irtibatı akamete uğrattı. Uzun yıllar kafasında kurguladığı düşüncelerin hayata geçmeye başladığı bir anda Selim'den gelen mektuba olumlu cevap vererek Mekke'den ayrıldı. Bidlîsîn nin Şah İsmail'den aldığı cevabî mektubun hemen ardından neden harekete geçmediği sorusuna gelince; mektubunda belirttiği gibi Şah'ın yardımıyla İstanbul'da adeta rehin tutulan çocuklarını getirtmek gibi bir düşünce taşıdığından onların da gelmesini sağladıktan sonra hep birlikte Tebriz’e gitmek düşüncesiyle açılanabilir.

35 II. Bayezid her ne kadar Safevilerle karşı karşıya gelmekten kaçınıp temkinli bir siyaset izlemeyi gerekli görüyorsa da zaman zaman gözdağı vermeyi gerekli gördü. II. Bayezid'in Şah İsmail'e yazdığı gözdağı içeren mektubu için bkz. Iranlı Tarihçilerin Kaleminden Çaldıran (1514), haz. Vural Genç, (İstanbul: Bengi Yayınları, 2011), s. 76-77.

36 Genç, "Acem’den Rum'a", s. 946-948; karşılaştırma için bkz. İdrîs-i Bidlîsî, Heşt Behişt, Nuruosmaniye, nr. 3209, vr. 635a. 
Bu ilk teşebbüs başarısızlıkla sonuçlansa bile Şah İsmail, Bidlîsî̀ yi yanına çekme fikrinden hiçbir zaman vazgeçmeyecek, firsat buldukça onu yanına davet edecekti. Çaldıran Savaşı'ndan sonra bile Şah İsmail, Urmiye civarında bulunan Bidlîsî̀yi yanına çekebilmek için kendi divan erkânından birisini göndermek gibi yoğun bir çaba sarf ettiyse de bu girişimleri de neticesiz kaldı. ${ }^{37}$ Bir sonraki teşebbüs çok geçmeden birkaç mektup aracilığı ile gerçekleşti. Şah İsmail ve Dîv Ali'nin "Kürdistan ümerasının bir araya getirilip toplanmasına ihtimam göstermesini ve karşıllı̆ında her isteğinin yerine getirileceğini ihtiva eden şahlık nişanı ve mektubunu" kendisine gönderdiklerinden bizzat Bidlîsî bahsetmektedir. ${ }^{38}$ Bidlîsînnin, Akkoyunlu sonrası hayatı boyunca himaye arayışı içindeyken birden fazla kez Acem ile Rum dünyası arasında kalıp neticede kendi menfaatlerine uygun bir tercih yapmak durumunda kaldığı açıktır. Ancak bu döneme ait külliyatı okunduğunda Osmanlı lehine aldığı hem ilk (II. Bayezid'in himayesi) hem de ikinci (I. Selim'in himayesi) kararından hiçbir şekilde memnun olmadığı görülecektir. Zengin ve güçlü bir haminin himayesi altında önemli bir konum elde etme hırsını her zaman içinde taşıyan Bidlîsî, yaşadığı hayal kırıklıklarını yanlış aldığı kararlara bağlayarak kendisini eleştirmekten de geri durmadı. Birbirine rakip hatta düşman olan hanedanlar arasındaki 16. yüzyılın başında yaşanan bu himaye arayışı, Akkoyunlu, Osmanlı ve Memlük sultanları adına eserler telif ettiği gibi Şah İsmail adına da eser telif etme isteği onu kendi çağının ulema ve bürokratları arasında daha farklı bir konuma taşımışıtır. Elde edilen yeni bilgiler ve bulgular, şimdiye dek yapılan ancak çeşitli problemler ve romantik yaklaşımlar içeren okumaların uzağında, yaratılan bu çarpık Bidlîsî imajının yeniden ele alınması ve sorgulanmasını elzem kilmaktadır.

37 Bidlîsî, Kürt beyleri ile müşavere etmek için Urmiye’ye geldiği bir anda Tebriz'de bulunan Şah İsmail onu kendi tarafına çekmek için kendi divan erkânından birisini gönderecek, Bradost Kürt ümerası arasındayken Şah’ın adamına gerekli cevabı verdiğini söyleyen Bidlîsî, takip edilir korkusuyla yerini değiştirecekti. Bkz. TSMA. E. 8333/2.

38 TSMA. E. 1019. 


\section{Ek 1: İdrîs-i Bidlîsî’nin Şab İsmail'e Kaside/Mektubu}

117 beyitten oluşan bu Farsça kaside/mektup, "Cevâb-1 Risâle-i Şâhîye” adı altında kaydedilmiş olup Bidlîsîn nin diğer birçok eserinin müstensihi olan Muhammed b. Bilâl tarafından orijinalinden istinsah edilmiştir. ${ }^{39}$ Müstensih mektubun içinde memduhun ima edildiği satırlarda Haydar-1 Sânî ifadesini gördüğünden metnin başlığının kenarına "be Haydar-1 sorhser nevişte/Kızılbaş Haydar'a yazmıştır” kaydını düşmüştür. 145b'deki derkenarlardan birinde Şah İsmail'in, Sultan Bayezid'e gönderdiği Şeybânî Han'ın kesik başının anlatıldığı kısımda müstensih bir kayıt düşerek "Hakan'in kesik başını getirmeleri olayı Sultan Bayezid ile Sultan Selim arasında bir fitne çıkardı. Buradan anlaşıldığına göre bu kaside Sultan Selim’in bilafeti zamanında Rum'dan gönderilmiştir. Doğrusunu Allah bilir" ifadesiyle olayın detayını verirken mektubun Mekke'de iken yazıldığı ayrıntısını tamamen atlamış, Selim zamanında Rum'dan yazılıp gönderildiği gibi bir hata içerisine düşmüştür. Oysa bu kesik baş gönderme hadisesi II. Bayezid zamanında yaşandığı gibi Özbek hanının başını gönderen de bizzat Şah İsmail'dir. Ayrıca Bidlı̂sî satırlarının sonunda Mekke olduğunu yazmasına rağmen müstensih bu yorumu yaparken bütün bu detayları atlayarak yanlış bir tanımlama içerisine girmiştir.

Kaside/mektubun Farsça'dan Türkçe’ye çevirisi aşağıdaki şekildedir:

\section{[144a] Cevâb-ı Risâle-i Şâhiye -be-Haydar-ı sorhser nevişte}

1- Yaşasın zamanın Şehinşâhı'nın suret ve manası! Dünya bir surettir ve cihanın canı gibi olan mana ise sensin.

2- Bu âlemdeki gerçekleri yazmak için Allah’tan sana varlık, senin düşmanına ise yokluk vacip oldu.

3- Bu dünya nebi ve velilerin çehrelerinin aynası gibidir, sen bunların arasinda bir göz bebeği nurusun.

4- Felek dahi Şah’ın fermanına boyun eğer, dönmesi için ondan izin alır, onun için ebede kadar ikbal, saadet ve firsat hekim içindir.

5- Dünya arsası senin ordunun karşısında daracık kalır, mana ülkesini ihsan ordunla fethet!

6- Kılıcının hükmü ten ülkesinde cari olunca, canın velayetinde gönüllerin şahlığına otur.

$39 \mathrm{Bu}$ kaside/mektuba ilk defa yukarıda bahsi geçen doktora çalışmamızda değinilmiş olup tam Türkçe metin ile Farsça orijinali ise burada verilecektir. 
7- Senin yüzünün nuru can gözümüzde bellidir, bu gizli gözlerden ah ü figanı silmiştir.

8- Bu senin velayetin Pîr'in aklı gibi kadimdir, Ali gibi civanmertsin, mülkün ve bahtın gençtir.

9- Şah'ın ortaya çıkışı såd ${ }^{40}$ burcundaki güneş gibidir, ancak saadet yıldızları güneşle birleşmiştir.

10- İslam'ın minberi Şah'ın adına okunan hutbeyle süslendi, bak gör ki onun kitabesinde ayet-i kürsi vardır.

11- Senin adına basılan sikkede büyük bir iksir mi var ki onun cevherinin nakşından dolayı altın ve gümüş de gülücük saçmaktadır.

12- Senin kılıcının hükmü karada ve denizde geçerlidir, çünkü ordun akan kum gibidir kılıcın da akan su gibidir.

13- Senin kılıcının cevheri savaş gününde serkeşlerin başını zincir gibi mızrakların başına dizer.

14- Sancağın tozun içinde dalgalanmaya başlayınca ölü gibi olan zaferin yüzündeki tozu da silkeleyip attı.

15- Savaşta çıkardığın tozlarla düşmanların gündüzünü geceye çevirirsin, ama senin alayındaki atlarının nallarından bin tane ay parıldar.

16- Senin binitin savaş tozlarının arasında bir gemi gibidir, düşmanın katran gibi kanıyla [gemin] kaplanmıştır.

17- Düşmanın boğazını kestikçe senin kılıcın daha da keskin olur, düşmanın hançeri senin hançerin için ancak bileme taşı olur.

18- [144b] Yedi iklim senin gazabının korkusundan kendisinden geçmiştir, senin k1lıcının dalgasından $s e b^{3} a^{41}$ titremektedir.

19- Senin kılıcının dili Dehhâk'ın yılanı gibi titremektedir ki düşmanın beynini yemiş ancak henüz doymamıştır.

20-Düşmanın sancağı [senin karşında] söğüt yaprağı gibi titrer, kılıcından çıkan yıldırımlarla düşmanın kalbi hafakanlara düşer.

21- Okun senin $z i h g i r^{42}$ parmağını öptüğünü görüp kıskanan yayın köşeleri eğilip senin elini öptü.

40 İki gezegen: Venüs, Jüpiter.

41 Yedi gezegen: Merkür, Venüs, Mars, Jüpiter, Satürn, Neptün, Plüton.

42 Başparmak. 
22- Senin düşman sürünün kelleleri kurtlara yem olunca, artık sürüsü kalmadığı için çobanın bir sürüye sahiplik etmesine ve kurttan korkmasına lüzum kalmaz.

23- Senin mızrağının darbesini yiyen kin dolu düşman, $\operatorname{seretan~}^{43}$ burcundan doğan şır ' $a^{44}$ yıldızı gibi olur.

24- Senin bast ü kabz halinden zahir olmuştur Murtazavî sıfatlar, zira hiçbir şah ve velî de korkaklık sıfatı olmaz.

25-Senin cömertlik elinle cennet kapısı açılmıştır, cehennemin kapısı da sen kılıcını kavrayınca kapanır.

26-Senin cömert elinin yaptığı bağış Ehl-i Beyt' in cömertliğini hikâye eder.

27-Senin yüce zatın dokuz tahtlı bir kubbedir, bağış denizinin kabarcıkları ise mavi gök kubbe gibidir.

28- Hızır'ın gemisi senin engin gönlünün cömertlik denizinde boğulur, hayat çeşmesi kaynağını senin avucundaki denizden alır.

29- Maden dahi senin elinin cömertliği karşısında iflas eder, el ve balyoz darbesiyle o madenden [senin madeninden] altın çekerler.

30- Şah'ın bağış ve ihsanı bizim beklentimizden fazla olunca tamah, niye istiyorsun zaten Şah veriyor diye kendi isteme elini dişiyle ısırdı.

31- Cömert elin gülün pençesi gibi altın saçmaya başlayınca goncanın heybesinde geriye hiç nakit kalmaz.

32- Sedef senin inciler saçan elinin şöhretini duyunca kendi sermayesizliğinden dolayı okyanus incisini satın aldı.

33- Şah'ın elini buluta benzetme, çünkü kimse bir bulutun gümüş ve altından ay ve güneş saçtığını görmemiştir.

34- Şah'ın düşmanı nasıl olur da İslam davasında bulunur, asıl iman gerçeği Ehl-i Beyt'i sevmektir.

35- [145a] Senin kılıcın Ali'nin Zülfikâr'ının mazharıdır, Ehl-i Beyt'in hakkını Mervan'dan almıştır.

36- Kılıcının kıvılcımları ve adaletinin suyuyla cihanı gül rengine, mülkü ise bostana çevirdin.

43 Yengeç burcu.

44 Büyük Köpek ve Küçük Köpek takımyıldızları. 
37- Cihan senin kılıcının döktüğü zalimlerin kanlarıyla ateş rengi güle döner.

38- Bu virane mülk senin adalet suyunla doymuş ve yeryüzü mamur ve abâd olmuştur.

39- Nazmın üstadı Kemâl İsmail, ${ }^{45}$ Sultan Celaleddin için söylediği fasih beyanlı medhi sanki senin [Şâh İsmail] için söylemiştir; Kemâl şöyle demiştir ki;

40- Bu zamanda senden başka bir şah var mıdır ki atının otu ve arpası Tiflis'ten suyu ise Umman'dan gelsin.

41- Senin azimet atın Hind ülkesinden kalkınca ikinci adımını Errân ülkesine koyar.

42- Kemâl, keşke duymuş olsaydı Şah'ın fetihlerini; Ermenistan Hoy'undan Şirvân’a kadar gittiğini,

43- Demir kılıcının darbesiyle İskender seddini açtı̆̆ını, Ye'cüc ordusunu gazaba uğratmak için dizginlerini o yöne çevirdiğini.

44- Senin atın bir yıldırım gibi harekete geçti, bir hamleyle Merv'e hücum etti; Hakan'ın üzerine.

45- Çingiz ve Moğol hanlarının doğu orduları, [o zamanda] Çingiz-i Sânî olan Muhammed Şeybân'a tabi idi.

46- Moğol, Tatar ve Kulmak'ların meydana getirdiği bu güruh, yaşlı genç üç yüz bin askerden oluşuyordu.

47- Şah’ın ordusu Irak mülkünden çıktı geldi, mesafeleri yıldırım gibi çabucak kat etmişti.

48- Hakan'ın Hind'ini ve fağfuri tacını Çingiz Han hanedanından bileğinin kuvvetiyle aldı.

45 Hallâku’l-Me'ânî, Kemâleddîn-i İsmail b. Cemâleddîn Muhammed b. Abdurrezzak-1 Isfahânî, İran'ın Moğol istilası dönemindeki büyük kasidecilerinin sonuncusu olup Moğollar tarafından 635/1237-38 yılında öldürülmüştür. Şiirinde taşıdığı ve ancak birkaç defa okunduktan sonra anlaşılabilecek ince manalar dolayısıyla manaların yaratıcısı anlamında "Hallâku'l-Me'ânı̂" olarak isimlendirilmiştir. Babası gibi Isfahân büyüklerini özellikle de Isfahân’’n Sa îdiye hanedanını ve Mâzenderân'daki Bâvendî hükümdarı Hüsâmdeddîn-i Erdeşîr ve Celâleddîn-i Harezmşâh gibi kendi döneminin kimi hükümdarlarını meşhur kasideleriyle övmüştür. Ayrıntılı bilgi için bkz. Ali Akbar Dehkhoda, Lughatname, (Tehran: Intisharat-e Danishgah-e Tehran, 1351), c. 22, s. 163-64. 
49- Bir keklik sürüsünün içine şahin gibi düşerek hepsinin kanatlarını uçarken kırıp helak etti.

50- Ceyhun Nehri'ni Tatar ordusunun kanıla Horasan mülkü arasında kıliciyla akıtt1.

51- Süleymanlık davasında bulunman senin azminden kaynaklanır, tahtın eğerindir, rüzgârının ise atındır.

52- [145b] Savaşın tozunu gören düşmanının korkusu ortaya çıktı, korkakların alnından kaçış izlerini gör ve oku.

53- Senin heybetin Rum'da zelzele yarattı, Kayser'in [II. Bayezid] kasrını yıkıp Kisrầnın [Şah İsmail] kubbesi kuruldu.

54- Senin korkundan Ben-i Asfar'ın ödü yarılır, senin kılıcının korkusundan dolayı benizleri sarıdır.

55- Senin kılıcının zinciri şahların boynunun gerdanlığıdır, şahların sana köle olduklarını gösteren amannameyi lütuf ile onlardan al.

56- Senin kılıç denizinin eğer bir dalgası Mısır’a ulaşacak olsa bilesin ki pramitlerin kubbesi Nil'in kumu gibi akar gider.

57- Hakan'ın [Muhammed Şeybânî] kesik başı senin fethini müjdeledi, senin kudret kılıcının ıslak dili onun [Hakan] kuru ve lal olmuş dilini konuşturmaya başladı.

58- Senin elçin Hakan'ın kesik başını Kayser'in [II. Bayezid] önüne götürünce [kayser] şaşkınlıkla senin bu mesajının düşüncesine daldı. ${ }^{46}$

59- Kisra’nın memleketi ve Hakan'ın tacı senindir, kükreyen aslan gibi velayetin cesaretinle iç içedir.

60-Sadece Hint racasından ve Rum kayserinden değil, doğudan batıya bütün sultanların tacinı ellerinden al.

61-Fetih [güneşi] senin ordunun öncü birliklerinden ayan olmuştur ki o güneşin kılıç ve mızrakları daima ileri atılır.

62-Savaş zamanı gayb ricali senin ordunun sağ ve sol cenahında yer alır, senin muhacirlerin devletinin ensar ve a'vanıdır.

46 Müstensih bu mısranın kenarına şu kaydı düşmüştür: "Hakan’ın kesik başını getirmeleri olayı Sultan Bayezid ile Sultan Selim arasında bir fitne çıkardı. Buradan anlaşıldığına göre bu kaside Sultan Selim'in hilafeti zamanında Rum'dan gönderilmiştir. Doğrusunu Allah bilir.” 
63-Şah’a layık övgü ve metihler yazmaya Şah'ın adını bereket olsun diye anan benim gibi bir dilencinin kuvveti yeter mi?

64- Bana şevk veren şey Şah'a dua etmektir, Hakk'ın ve Şah'ın adını zikrederek gönlüme huzur vereyim.

$65-\ldots{ }^{47}$

66- Yüz dil de olsa senin vasfının hakkı verilemez, bu yüzden bu kulun kalemi de tepeden tırnağa dil olmuştur.

67-Kur'an'ın içi baştanbaşa Ehl-i Beyt'e olan selam ve esenlikle dolu olduğu için Ehl-i Beyt'in özü olan o Şah'ı övmeye ben layık değilim.

68-Herkes Şah'a dua eder, ben herkesten daha fazla ederim, peygambere naat yazmada herkes Hassân ${ }^{48}$ gibi olamaz.

69- [146a] Ömrümün kalanını Şah’ı methetmekle geçirsem de yine dili kesik olan bu kalemin ayıbından kurtulamam.

70- Bu kara yüzlü kalem Şah’ın zamanında diğerlerinin mehdini yazdı diye utancından yüzünü önüne eğdi.

$71-\ldots{ }^{49}$

72- Kulun hatası ve kusuru için Şah'ın geniş lütfünden daha iyi bağışlayıcı yoktur, tek ümidim ve sığındığım şey Şah’ın beni bağışlayacağını bilmemdir.

73- Kulluktaki kusurlarım dolayısıyla özür dilemek için gönlüm her gün azim kanadıyla Şah'a doğru uçmak istiyordu.

74- Cömertlik yolundan, gaipten bir kişi geldi; onun kutlu adımı, muradını alamayanların susuz dudakları için bir ırmaktı.

75- Kutlu fal, onun süsünün nurundan bir misaldir, o kutlu falın ünvanı onun tuğrasının büyük adıdır.

76-Şah'ın mektubu yoksa her bir sayfası içinde Kur'an'ın özetle yazıldığı Cebrail'in kanatları miydı?

47 Bu satırlar istinsah edilmiş metinde boş bırakılmış kenarına şu Farsça kayıt düşülmüştür:

"Buradaki bir beyitin üstü çizilmiştir. Bundan dolayı ondan mana çıkarmak mümkün değildi. Açıkçası bu beyitte methedilen kişinin adı verilmiştir."

48 Hassân b. Sabit, Hz. Muhammed dönemi şairlerinden olup Peygamber'e yazdığı ünlü şiirleriyle bilinir.

49 Satır istinsah edilmiş metinde de olmayıp yeri boş bırakılmış yanına şu Farsça kayıt düşülmüştür: "Burada da bir beyitin üzeri çizilmiştir." 
77- Elindeki mektup o kadar uzundu ki sanki dokuz gök tabakası onun içinde katlanmıştı ve Şah'ın ismi dünyayı zapt eden bir güneş gibi onun içinde görünüyordu.

78- Şah’ın kâtibinin yazdığı sadece söz değildi, adeta gökte gezen hüma kuşu, kanatlarının gölgesini onun üzerine atmıştı.

79- Senin kâtibinin kalemi, kurtulma kanadından beyan meydanına parmak kanatlarını açan bir hümadır.

80- Onun mührü güneş gibi ışık saçar ve gök gibi yuvarlaktır, Şah’ın kutlu adının güneşi de o [mühürde] dolaşmaktadır.

81- Kötü gözlerin göremeyeceği bir yerde başıma koydum ve katladım, ondan kötü gözlere karşı kendime muska yaptım.

82- Vahiy gibi insanların gözlerinden uzak olan o sayfaları gizlice okudum.

83-Şah'ın elçisinin elindeki mektubu on parmak gibiydi ve Şah'ın bütün erkânının lütuflarını bana getirmişti.

84- Şah'ın ve bütün erkânın bu fakir İdrîs'e duyduğu muhabbet ve bulunduğu lütuflar, şahlığı kendisine doğuştan verilmiş olan Şah’ın bağış ve rahmetinin, büyüklüğünün nişanesidir.

85- Onları başımın üzerine koyarak onunla iftihar ettim, uyulması vacip olan bu kutlu emre boyun eğdim.

86- [146b] Nasıl ki eman yüzüğü ve eman fermanı bir kişinin eline geçer de onun korkan yüreğine sevinç gelirse, Şah'ın bu mektubu da beni öyle sevindirdi.

87-Ayrılık acısı çeken bir hasta için sevgilinin sohbet müjdesinin gelerek ve beden sıhhatini kazanması ne büyük mutluluktur.

88-Yüce şahlık hükmüyle bu menşurun içinde bu kulun adının kâtibin kalemiyle yazılması ne büyük saadettir.

89- Umut ederim ki Şah’ın kulları ve hizmetçileri bu hakir kulun adını unutmamışlardır.

90- Şah'ın şöhretli adı onun vefa vasfiyla iç içedir, vaadinde duran doğru bir kişi olduğu için Allah onu övmüştür.

91-Senin güneş gibi vakarlı olan hükmün maşrık ve mağripte geçerli ve ışıldamaktadır. 
92-Şah'ın dergâhının kadim olan bu gulamının ayrılıp, hicranın karanlık çöllerine düşmesi reva mıydı?

93- Gâh şeytan siretli birkaç rindle uğraşmış, gâh dalkavuk ve cahillerin esiri olmuştum.

94- Bela içinde ayrılık acısı çekerken bazen sahile ulaşacağı ümidinden vazgeçmiş, bazen de sergerdan bir şekilde sapkınlığın susuz çöllerine düşmüştüm.

95- Şimdi yorgun bir kuş gibi düştüğüm tuzaktan çıktım, ama evlatlarımın ayrılığından gözlerim hala ağlamaklı.

$96-\ldots{ }^{50}$ mihnet ve tufan deryasından kurtardı.

97- [birkaç kelime yok] [Allah'ın]...emriyle Şah'ın devletinin uğur ve bereketiyle, bütün gamlarımdan uzaklaştım ve müşküllerim halloldu.

98-Her ne kadar ayrılık akşamım şaşkınlığa düşmüşse de vadi-i eymenin kandillerini görmeyi ümit ediyorum.

99- Mahpus olduğum kafesten kaçıp kurtulan kuş benim, evlatlarımın ayrılı̆̆ının acısından zindanda gibiyim.

100- Kullarının efendisi olan Şah'ın [Şah İsmail] inayeti ve yardımıyla bütün müptelalar belalarından kurtulsa ne olur?

101- Mana Kâbesi'nin şevkinden... ${ }^{51}$, Mekke’nin dikenli çöllerine düşmüşüm.

102- Gözyaşı damlalarından, dizginleri kirpik olan bin kızıl deveyi yola katar eyledim.

103- [147a] Develeri okuduğu şarkılarla yürüten adamdan duyduğum her ses ile gözlerimden sel gibi akan yaşlarla gözyaşı katarı dizdim.

104- Kalbimdeki delikler ve kanlı gözlerimdeki yaşlarla akik vadisinin yollarında seller akıttım.

105- Suret Kâbe'sinden, hac manasına varayım, zira Şah'ın mahallini tavaf etmekle Kâbe'yi tavaf etmek aslında aynı şeydir.

50 İstinsah edilmiş metinde ilk mısranın yeri boş bırakılmış olup "burada bir mısranın üzeri çizilmişti” kaydı düşülmüştür.

51 İstinsah edilmiş metinde ilk mısranın devamındaki yer boş bırakılmış olup "burada bir mısranın üzeri çizilmişti” kaydı düşülmüştür. 
106- Gerçi benim gönlümün yüzü daima senin kapının kıblesindeydi ama bu pişmanlık ve üzüntü içinde bulunan kulun daha fazla takati kalmamıştır.

107- Ömrümün geri kalanını Şah’’n devletine dua ederek nesir kitaplar ve nazım divanlar yazmayı ümit ediyorum.

108- Fakirliğimden başka bir hediyem olmadığı için kapısına varınca bilgin Şah’a ilim hediyesi götüreyim.

109- Feth-i mübin ümidi Ali'nin sancağının bulunduğu kapıdan görünür, şimdi Haydar-1 Sânî [Şah İsmail] cihanın mülkünü fethetmiştir. ${ }^{52}$

110- Ali'nin hem kılıcı hem de cömertliği sana geçmiştir, şimdi Murtaza’nın ilim sancağıyla cevelan et!

111- Atalarında olduğu gibi senin iktidarın da velayetinden gelir, adalet ve ilim nişaneni bir delil ile ortaya çıkar.

112- Tahtının yanında âlimlerden bir meclis kur öyle bir güruhun toplantısı ki hepsi insanın hası ve özü olsun.

113- Yaratıcı aynı atalarına bir zamanlar verdiği gibi sana da ilm-i ledün vermiştir, Hızır gibi hayat suyunu her yandan ilim ehline fışkırt!

114- Din ordusu neden her yandan perişanlık ve zar içindedir, sen dinin şahısın onların gönüllerini tekrar yap!

115- Şahların iki koluna da kuvvet veren mülk ve din, ikiz kardeş gibi oldukça,

116- Nuh gibi uzun ömürlü, İskender gibi mülk sahibi olasın, Ali'nin adaletine ve Lokman'ın hikmetine sahip olasın.

117- Kılıç tutan elin mülkü fethetmek için kefildir, bağış saçan elinin gerçekleştirdiği fetihler ise halkın rızkının güvencesidir.

118- Bitti.

52 Satırın sonundaki Farsça derkenarda müstensih, memduhun adının açıkça zikredildiğini belirtir. 
VURAL GENÇ

Ek 2: Farsça Metin

$1 \varepsilon \varepsilon$

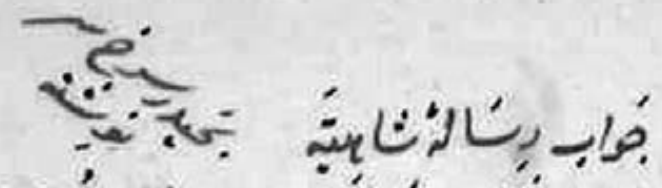

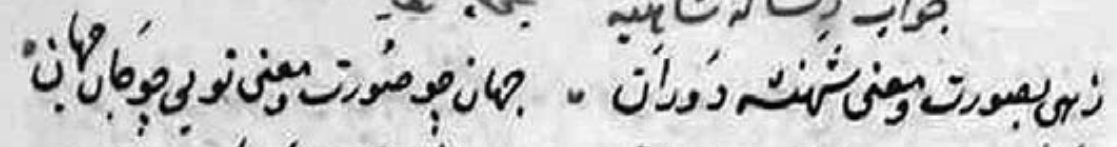

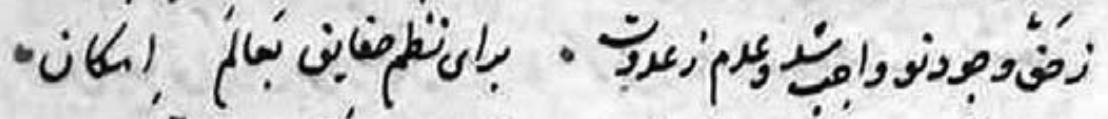

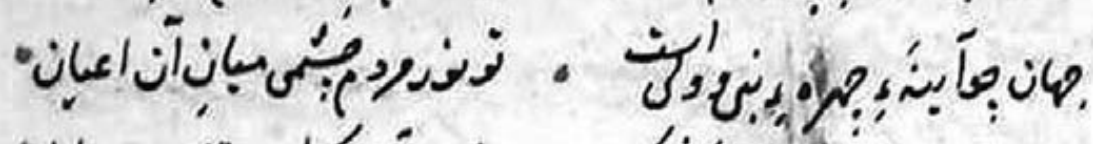

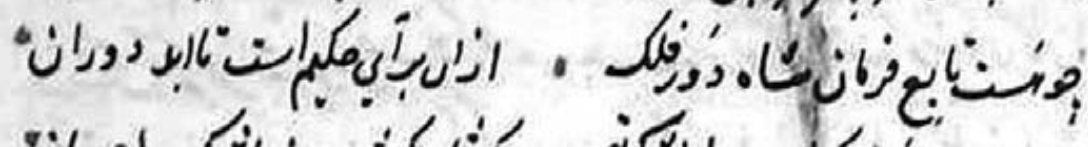

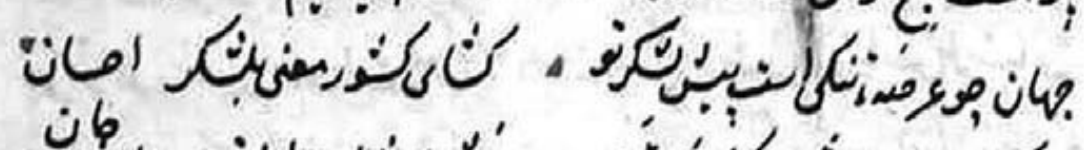

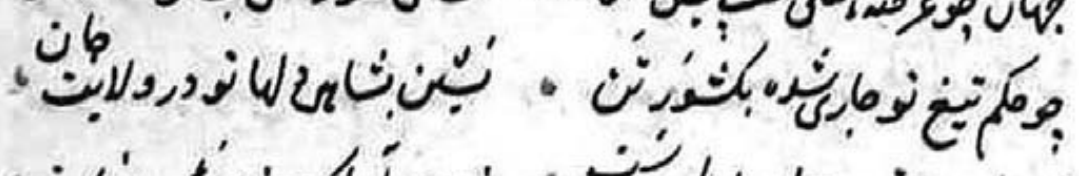

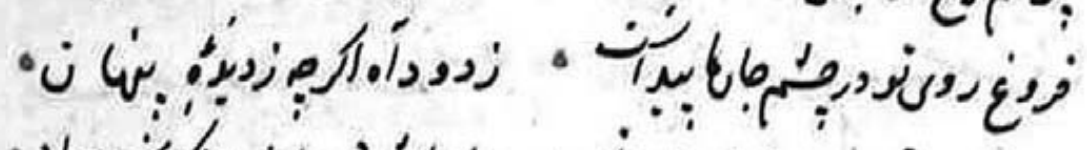

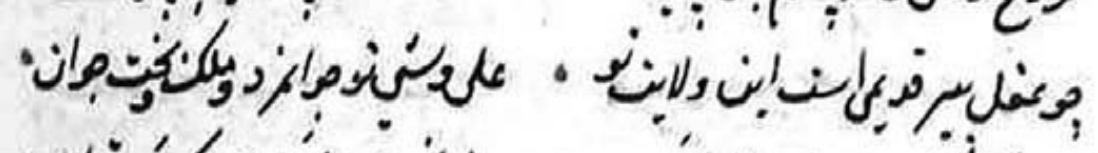

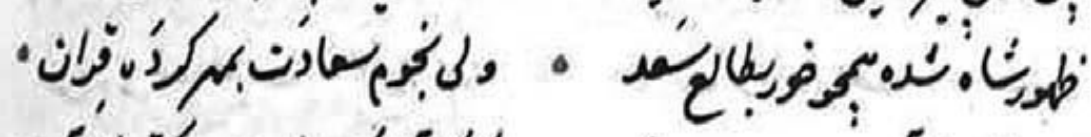

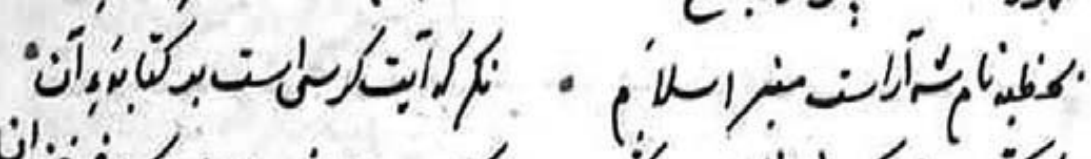

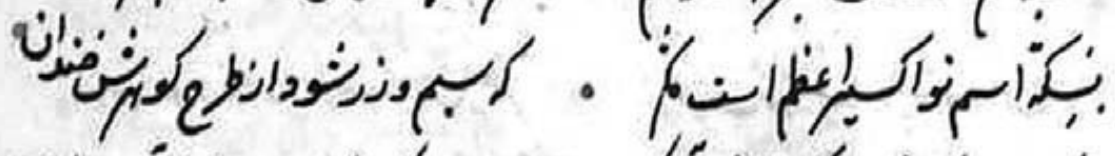

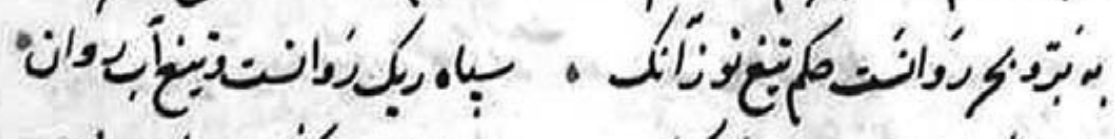

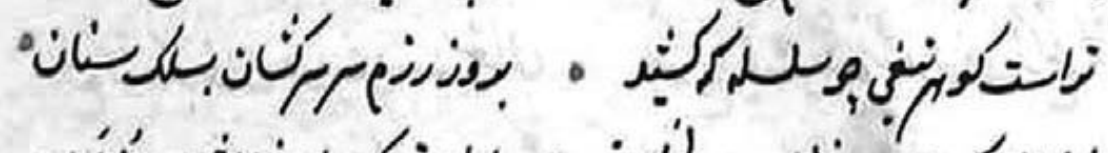

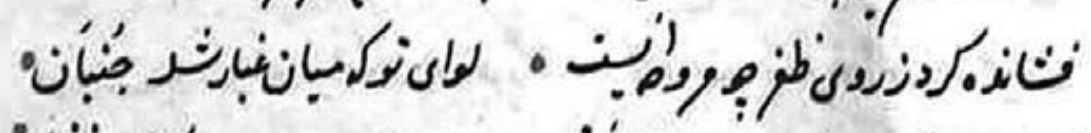

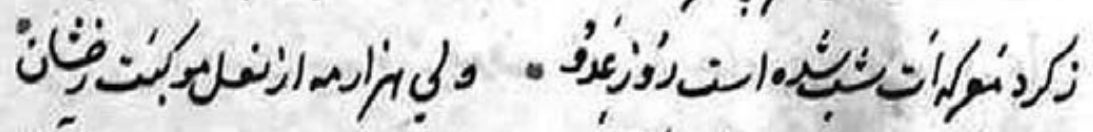

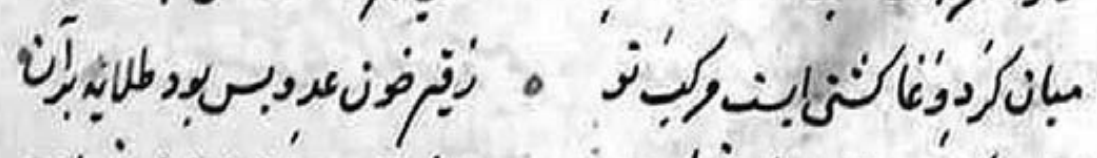

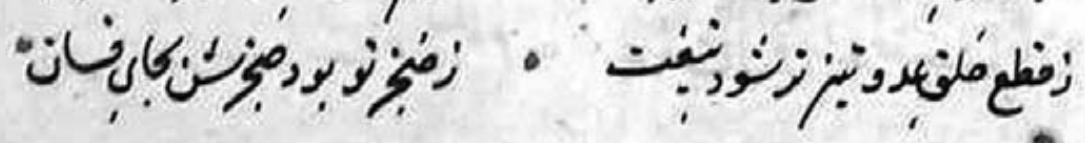

67 


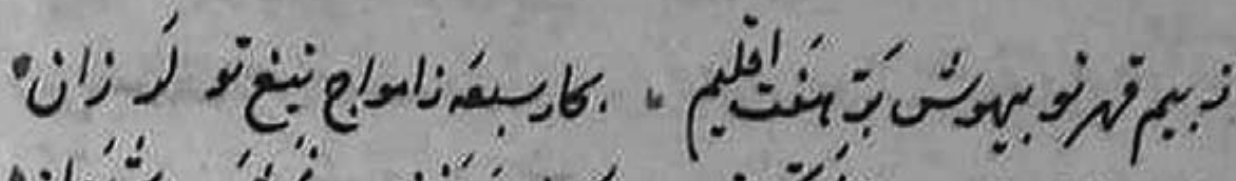

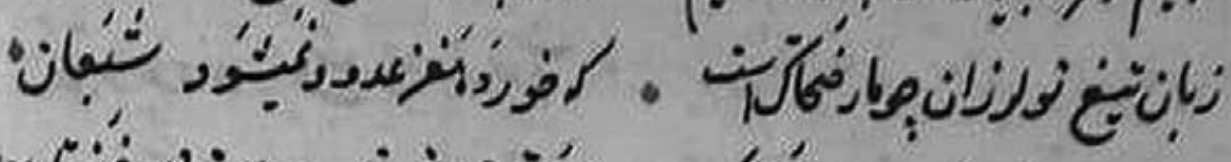

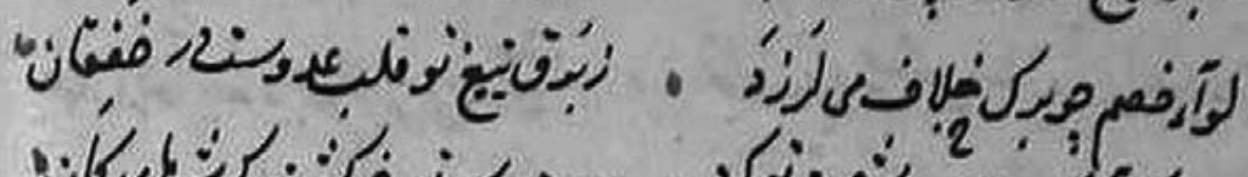

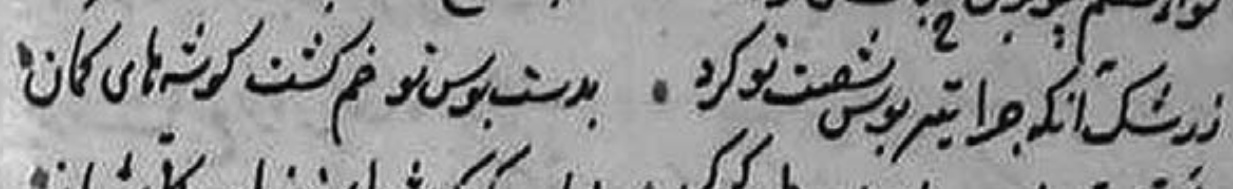

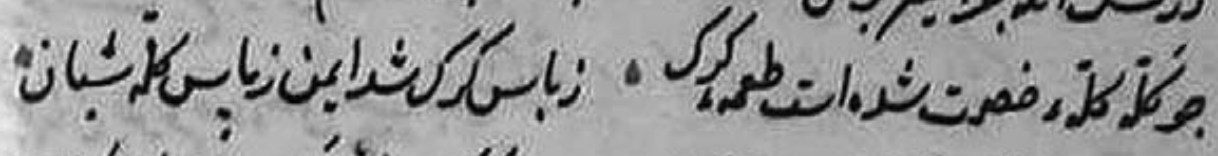

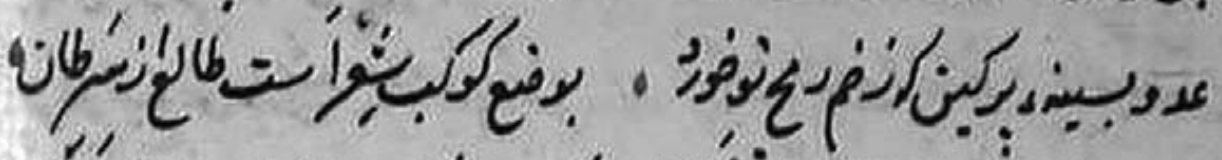

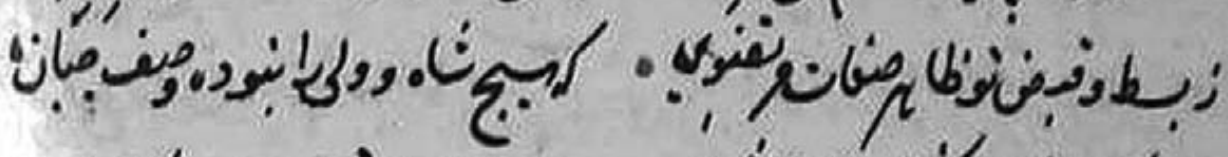

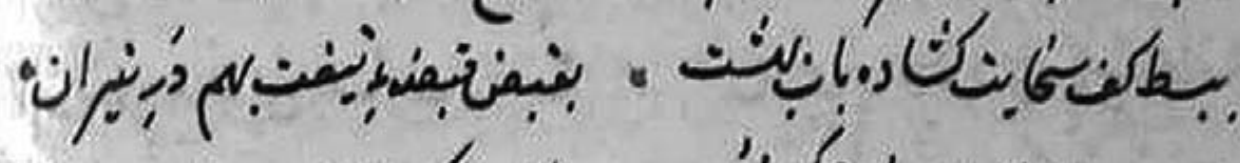

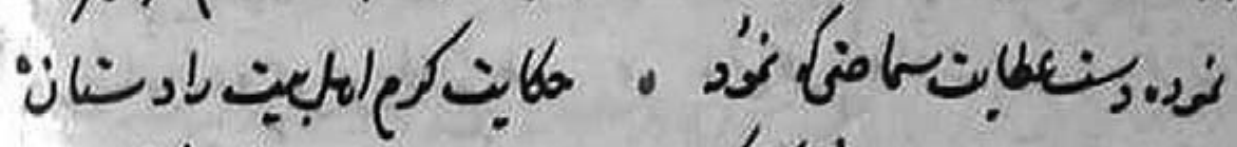

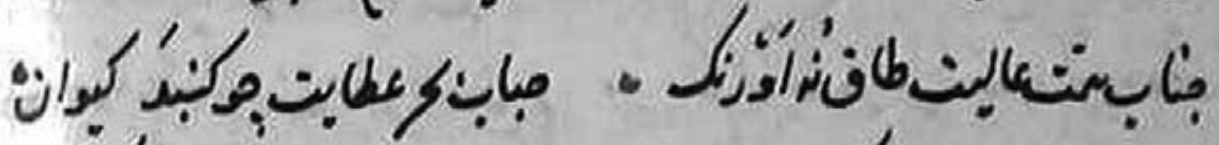

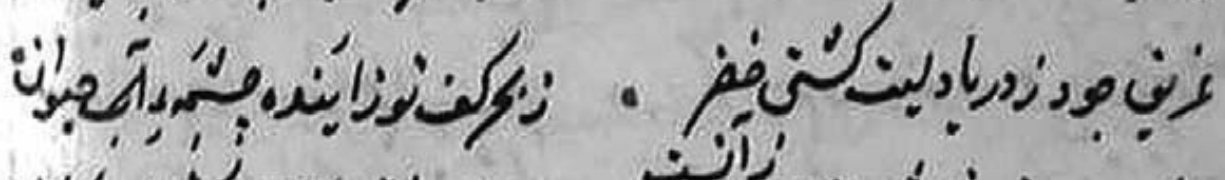

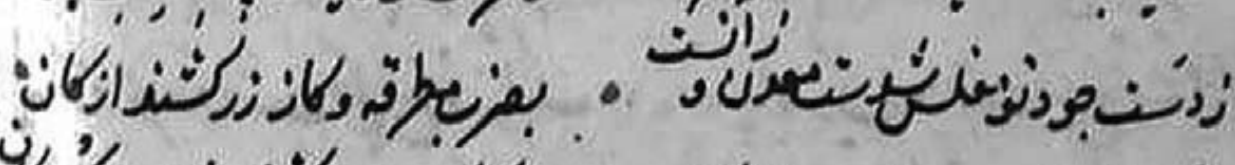

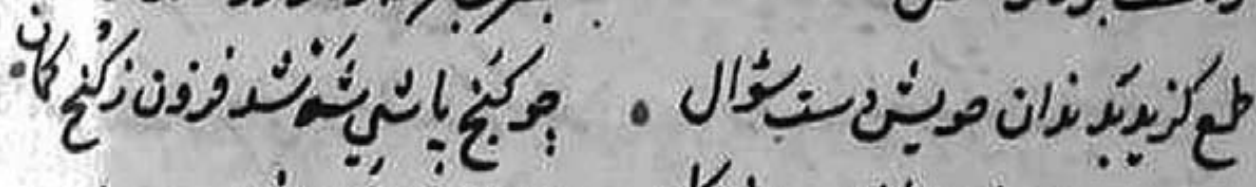

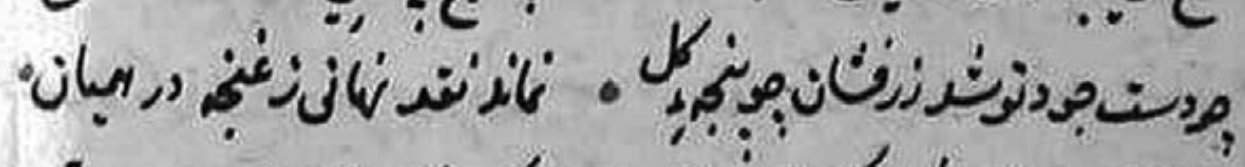

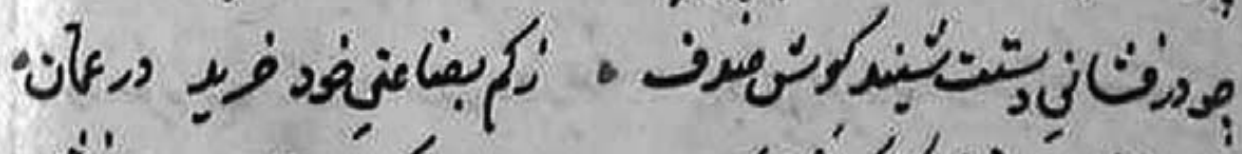

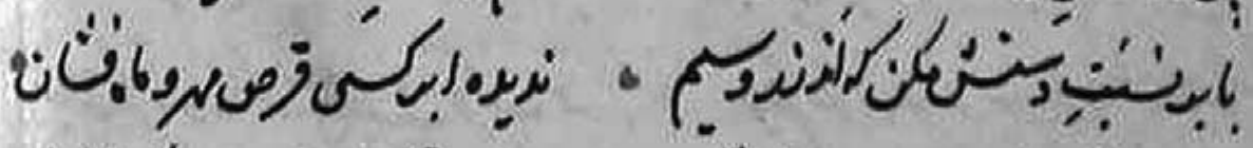

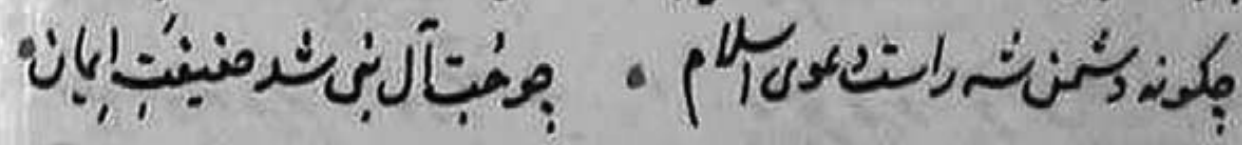




\section{0}

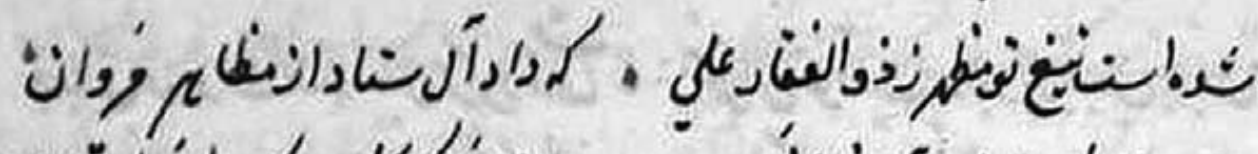

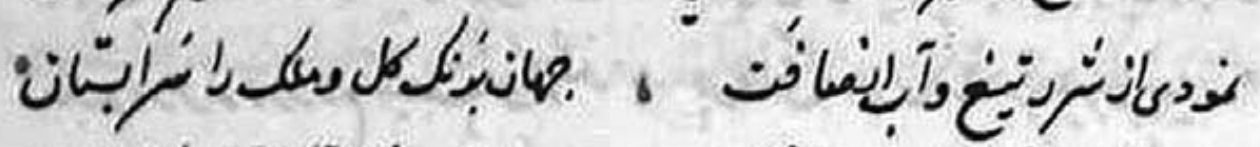

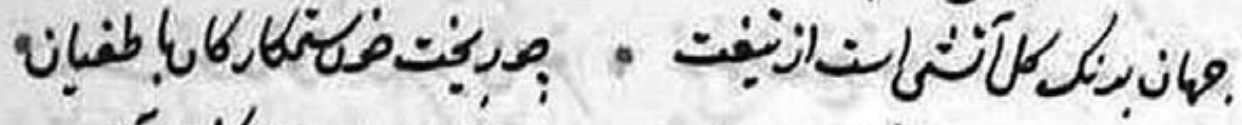

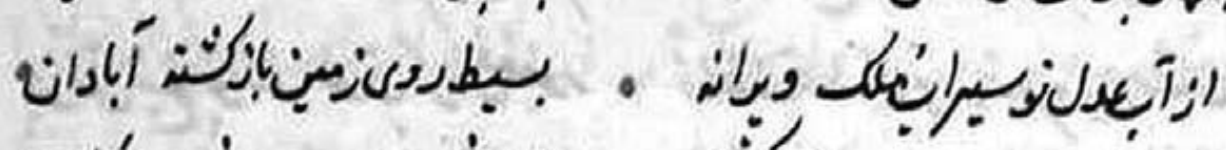

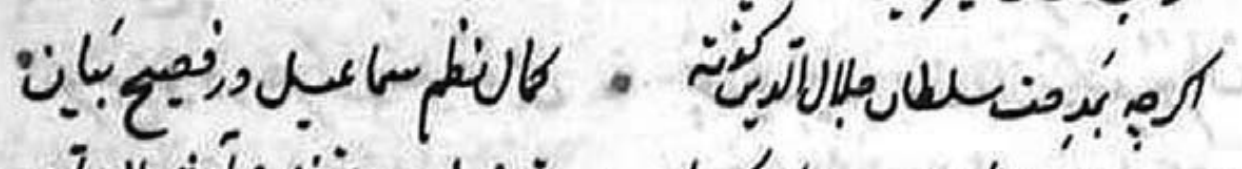

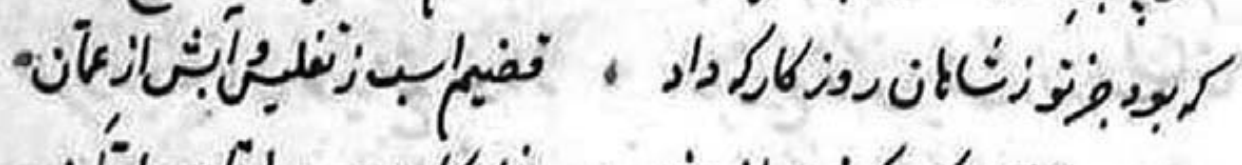

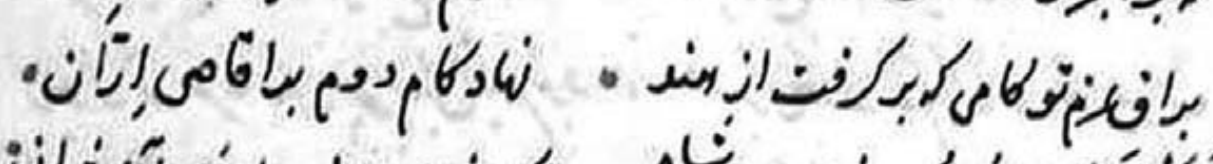

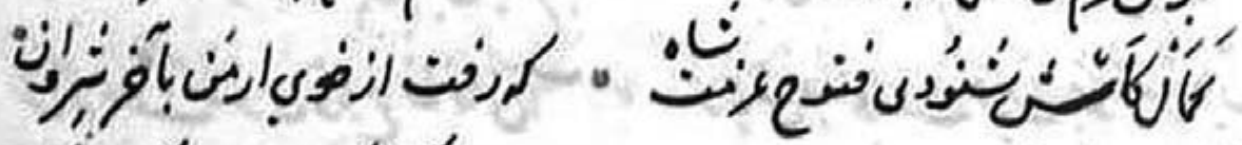

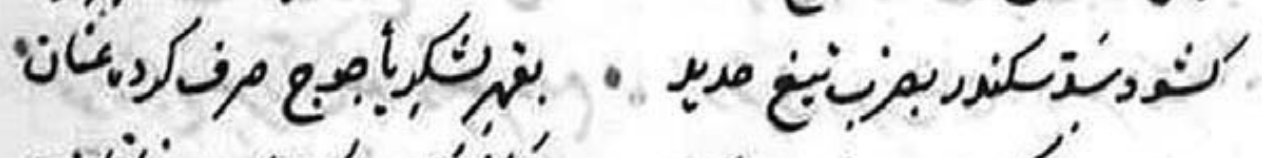

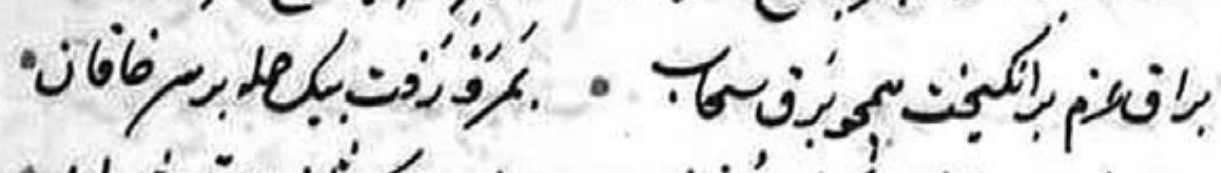

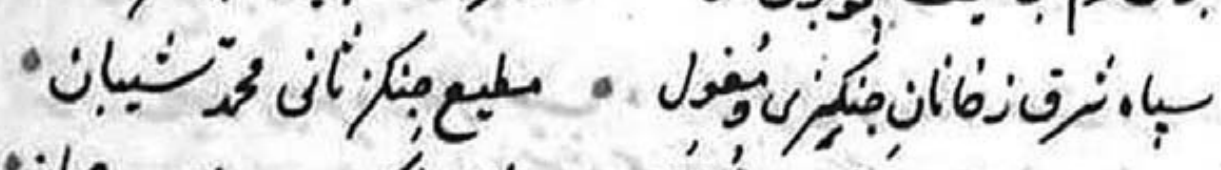

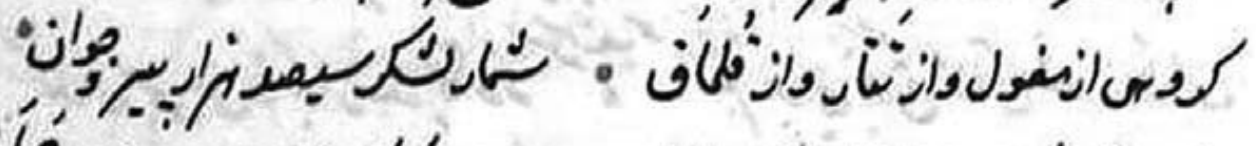

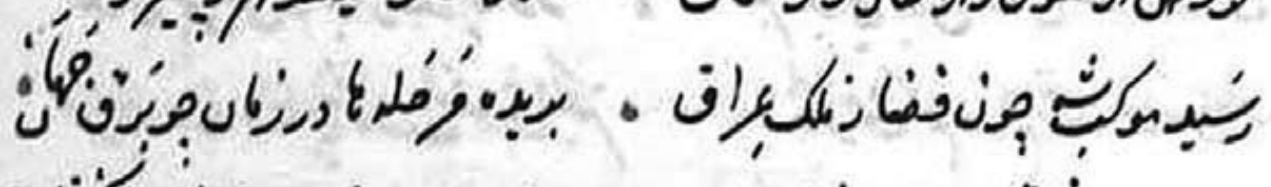

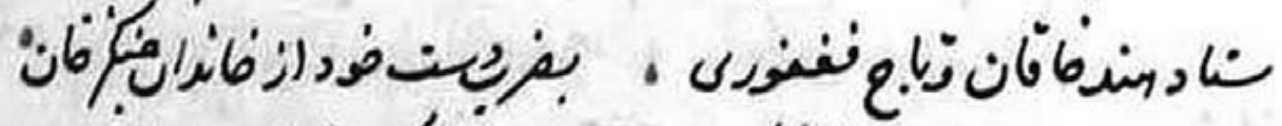

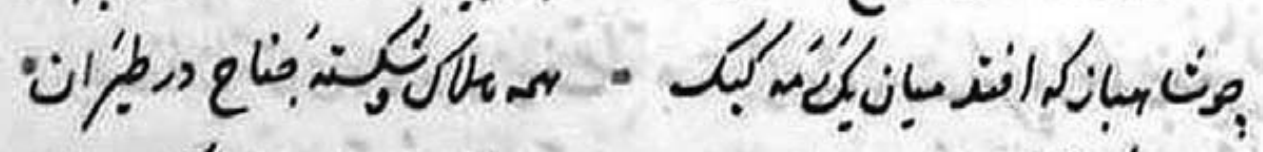

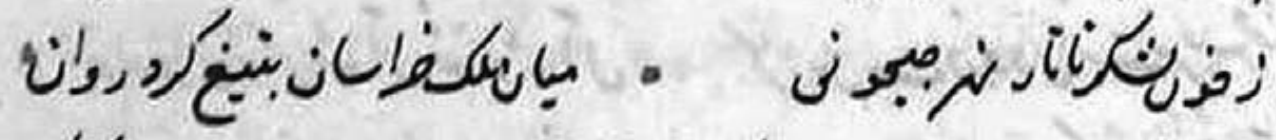

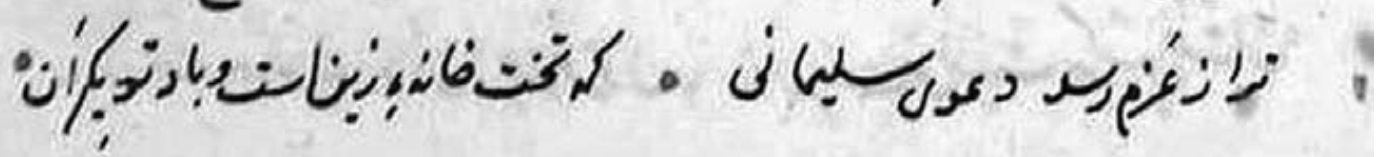




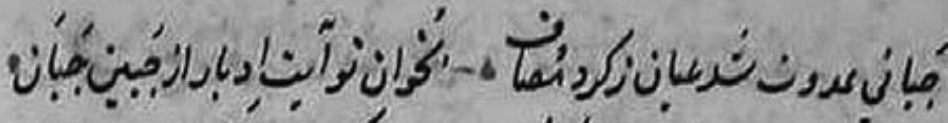

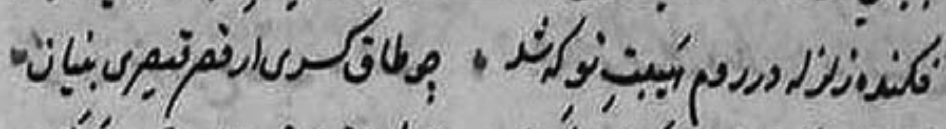

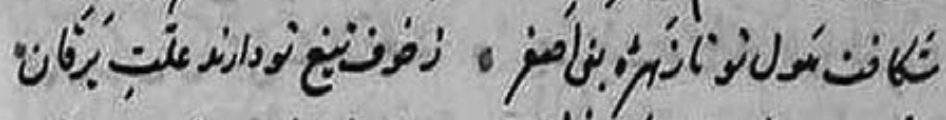

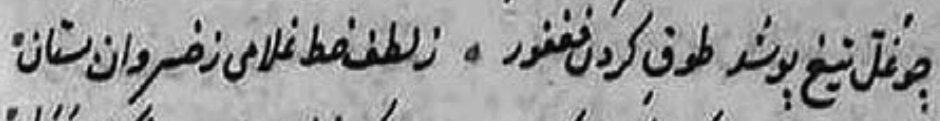

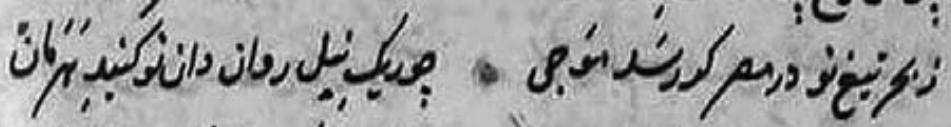

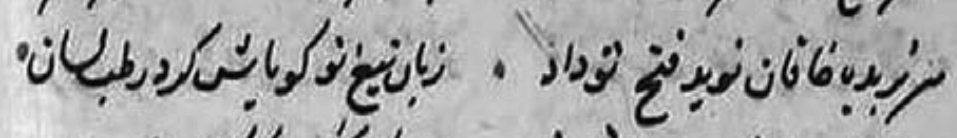

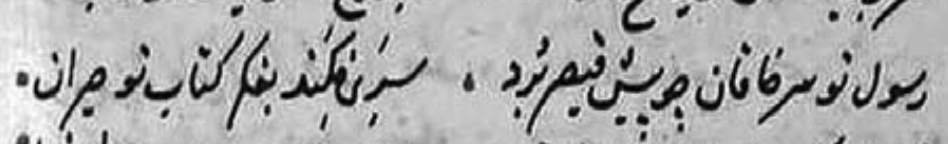
زمأك

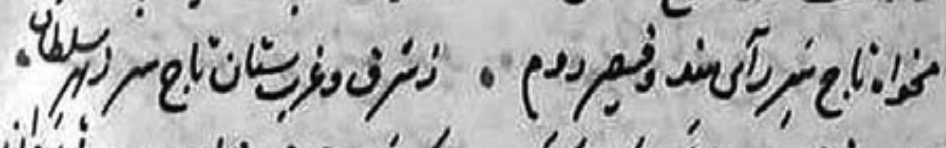

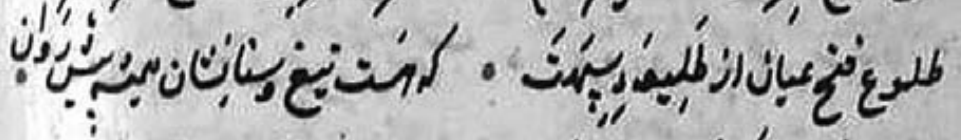

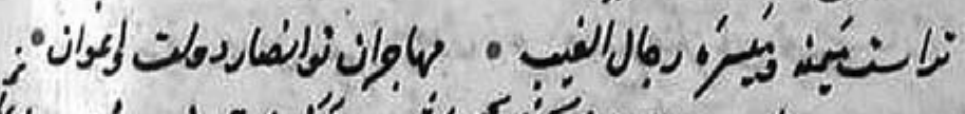

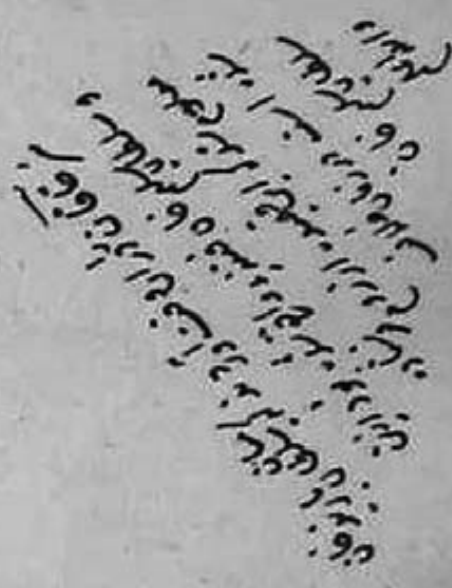

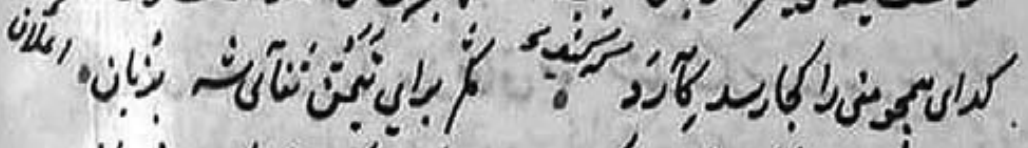

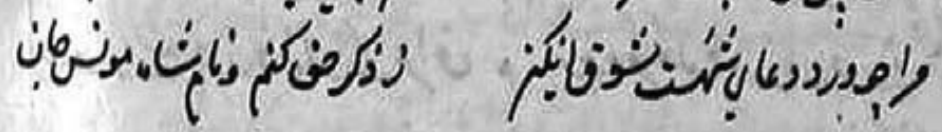

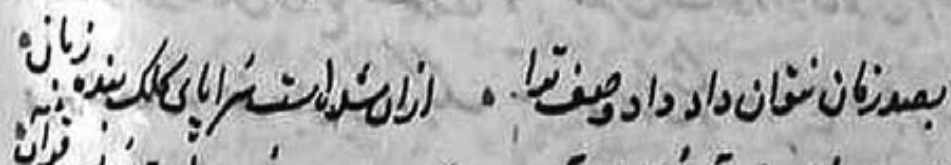

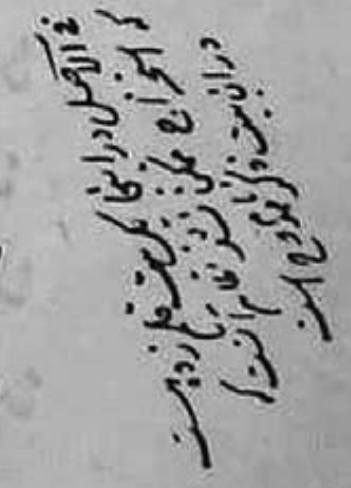




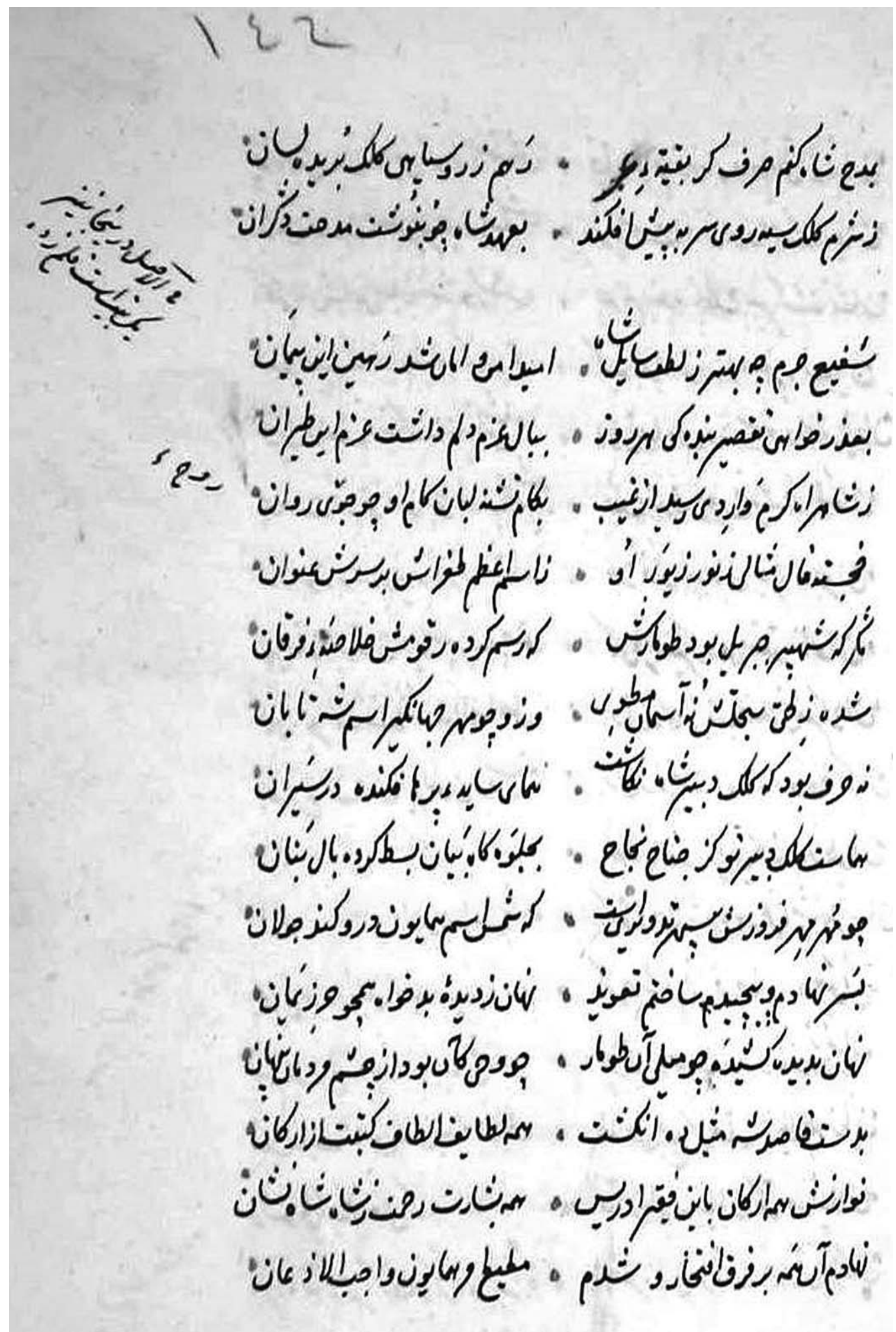




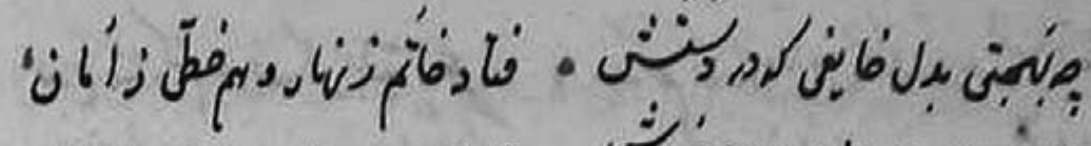
ن

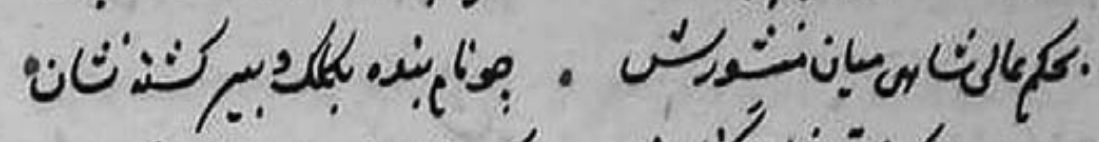

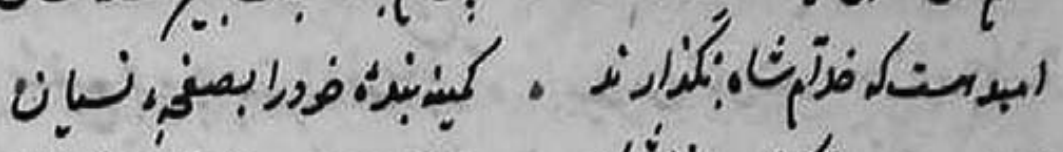

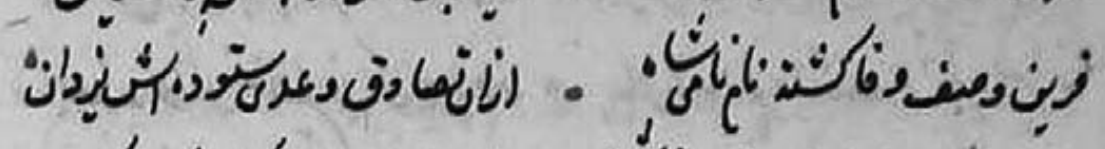

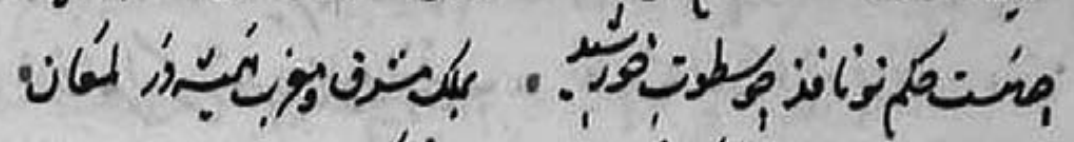

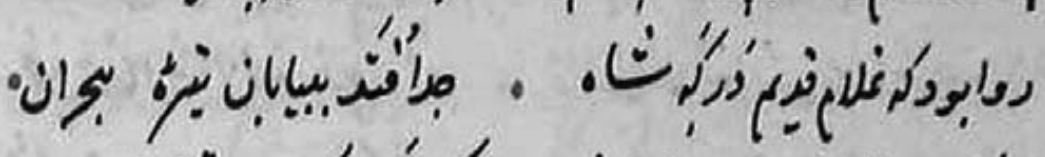

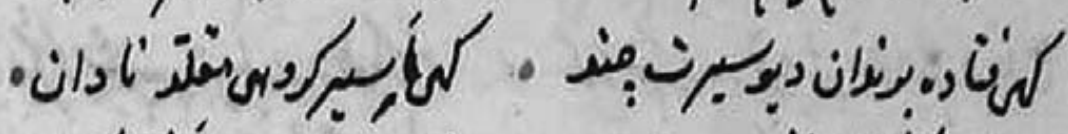

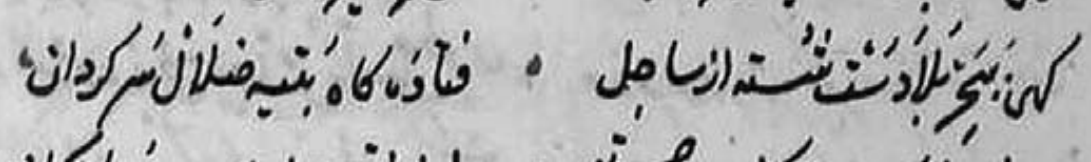

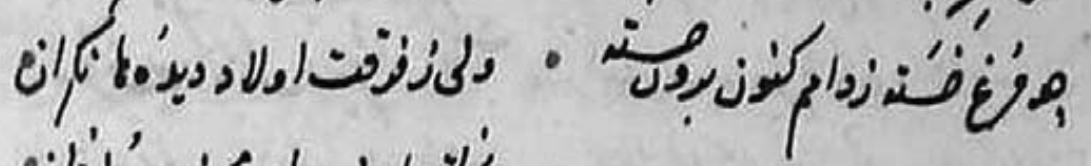

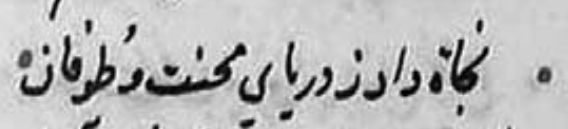

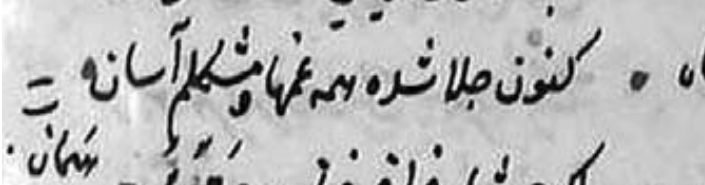

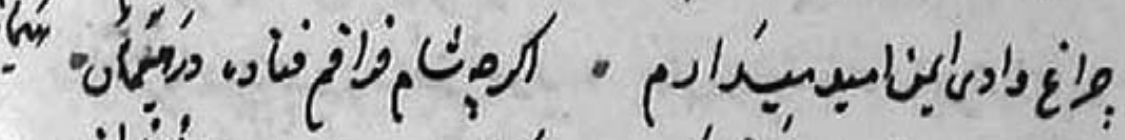

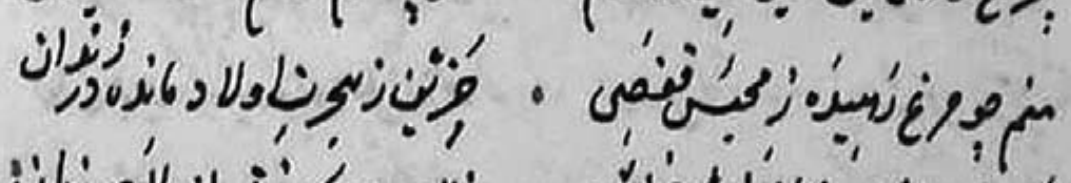

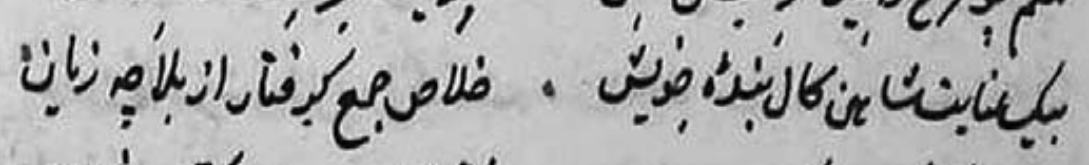

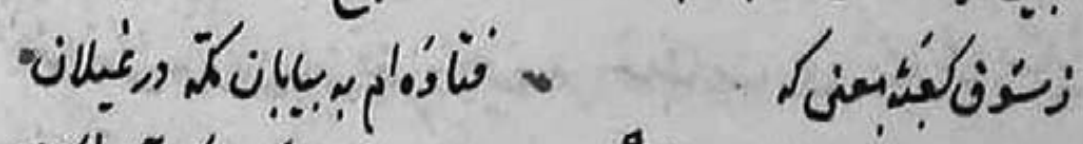

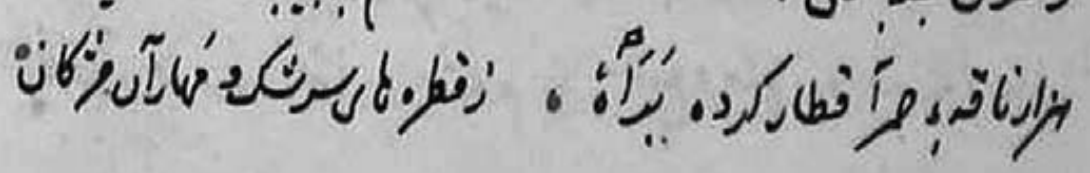
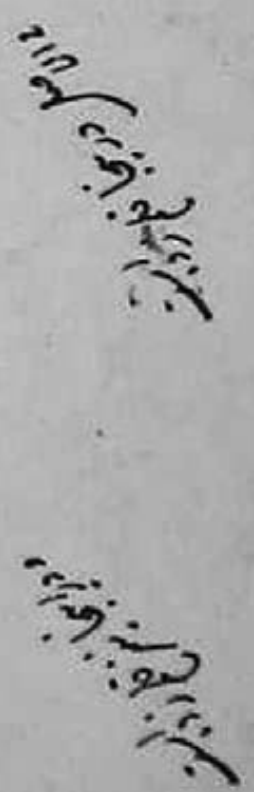


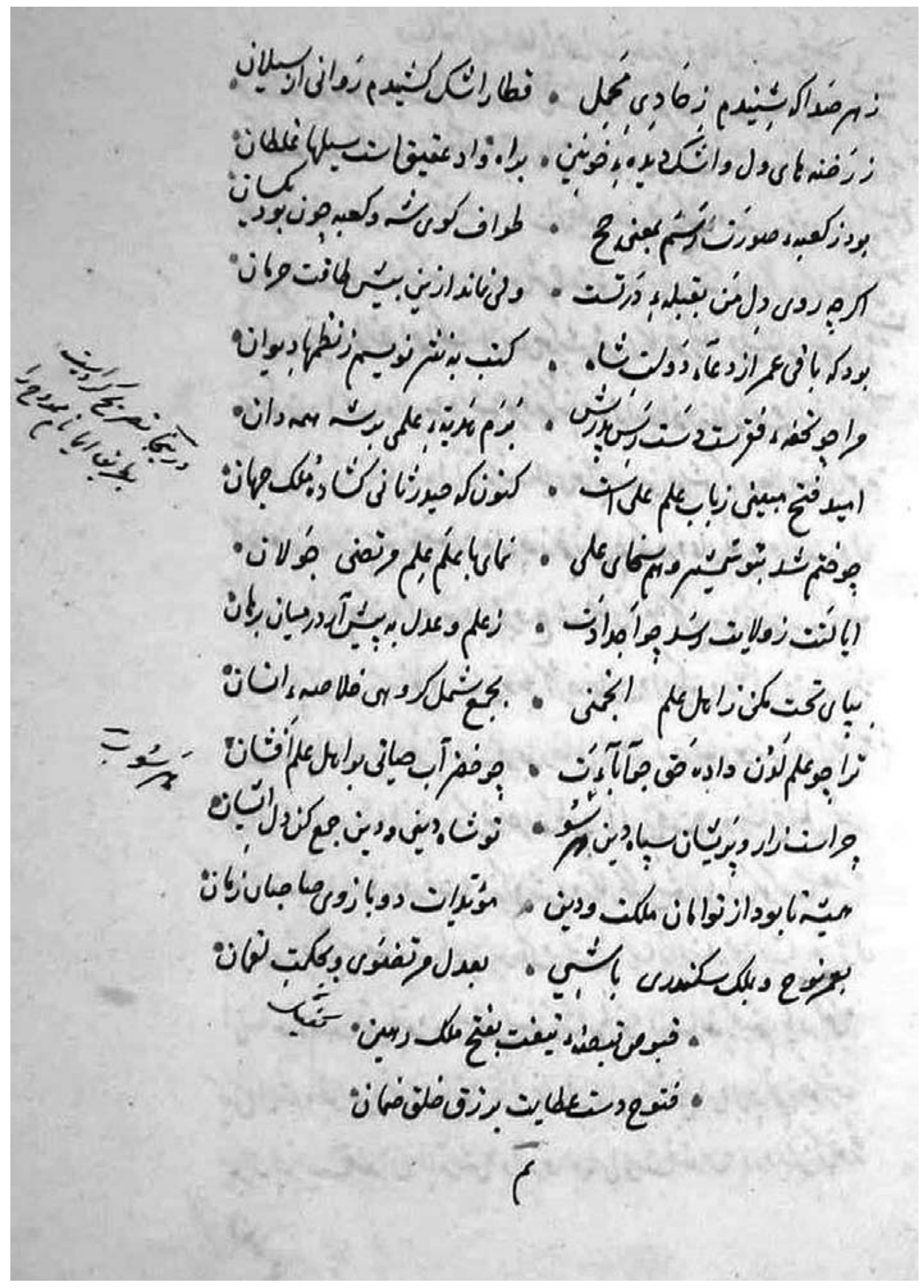


Şah ile Sultan Arasında Bir Acem Bürokratı: İdrîs-i Bidlîsî̀nin Şah İsmail'in Himayesine Girme Çabası

Öz — İdrîs-i Bidlîsî, (1457-1520) modern araştırmacıların üzerinde sıklıkla durduğu, günümüz tarih yazımında da hafızalarda canlı kalabilen, devam edegelen bazı tarihsel tartışmaların bugün dahi merkezinde olan 16. yüzyıl Osmanlı dünyasının nadir figürlerinden biridir. Bir bürokrat ve tarihçi olarak o, 15. yüzyıl sonu ve 16 . yüzyılın başında önce Osmanlı-Akkoyunlu, ardından Osmanlı-Memlük ve Osman-

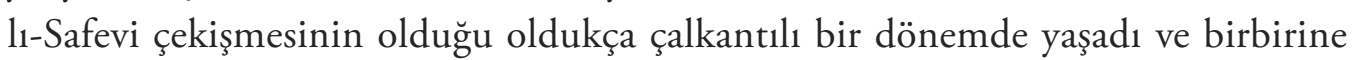
düşman olan bu her dört hanedan ile de farklı zamanlarda ilişki kurdu. Çoğunlukla II. Bayezid'in ve I. Selim'in himayesiyle anılsa da aslında, yaşadığı siyasal atmosferde birden fazla hami edinme teşebbüslerinde bulundu. Bunlardan biri de hiç kuşkusuz Şah İsmail'dir. Burada yeni bulunan bir belge üzerinden Bidlîsînin II. Bayezid’in himayesinden çıkmasının ardından daha İstanbul'da iken planladığı üzere yeni bir hami bulmak adına geldiği Mekke'de Şah İsmail'e intisap etme çabası ortaya konulmuştur.

Anahtar kelimeler: İdrîs-i Bidlîsî, Şah İsmail, II. Bayezid, I. Selim, Osmanlılar, Safeviler

\section{Bibliyografya}

\section{Yayımlanmış Eserler}

Dehkhoda, Ali Akbar: Lughatname, Tehran: Intisharat-e Danishgah-e Tehran 1351, c. 22, s. $163-64$.

Emecen, Feridun M.: Yavuz Sultan Selim, İstanbul: Yitik Hazine Yayınları 2010.

Emecen, Feridun M.: II. Bâyezîd'in Tarih Merakı Üzerine Bir Not: Fenarîzâde Alâeddîn Alînin Anonim Osmanlı Tarihi Derlemesi”, Kitaplara Vakfedilen Bir Ömre Tuhfe: Ísmail E. Erünsal'a Armăgan, haz. Hatice Aynur, Bilgin Aydın, Mustafa Birol Ülker, İstanbul: Ülke Yayınları 2014, s. 331-344.

Esnad va Mukatebat-e Tarikhi-e Iran az Timur ta Shah Ismail Hamrah ba Yaddashtha-ye Tafsili, haz. Abd al-Husayn Navai, Tehran: Muassasa-ye Mutalaat-e Islami 1370.

Fazl Allah Ibn Ruzbihan Khunji Isfahani: Tarikh-i Alam Aray-i Amini, haz. Muhammed Akbar Ashiq, Tehran: Anjuman-e Asar va Mafakhir-e Farhangi 2003.

Genç, Vural: “Acem'den Rum'a”: Idris-i Bidlîsînin Hayatı, Tarihçiliği ve Heşt Behişt’in II. Bayezid Kısmı (1481-1512)", (yayımlanmamış doktora tezi) İstanbul: İstanbul Üniversitesi Sosyal Bilimler Enstitüsü, 2014. 
Heidarizadeh, Tofigh: "Muhajerat-e Ulema-ye Iran be Impraturi-ye Osmanî”, Majalle-ye Farhang, 20-21 (Tehran 1375/1997), s. 49-94.

İnalc1k, Halil: Şair ve Patron: Patrimonyal Devlet ve Sanat Üzerinde Sosyolojik Bir Inceleme, Ankara: Doğu Batı Yayınları 2003.

İranlı Tarihçilerin Kaleminden Çaldıran (1514), haz. Vural Genç, İstanbul: Bengi Yayınları 2011.

Kut, Günay: Heşt Bihişt: The Tezkire by Sehî Beg, Sources of Oriental Languages and Literatures 5, Şinasi Tekin-Gönül Alpay Tekin (ed.), Cambridge, Mass.: Harvard University 1987.

Muhŷ̀-i Gülşenî: Menâkıb-ı İbrahim Gülşenı̂, haz. Tahsin Yazıcı, Ankara: TTK Yayınları 1982.

Rijâl-e Kitab-e Habib al-siyar, haz. Abd al-Husayn Navai, Tehran: Anjuman-e Asar va Mafakhir-e Farhangi 1379.

Şeref Han Bidlîsî: Şerefnâme: Tarikh-e Mufassal-e Kurdistan, nşr. V. Veliaminof Zernof, c. 1, Tehran: Intisharat-e Esatir 1377.

\section{Yazma Eserler ve Arşiv Belgeleri}

İdrîs-i Bidlîsî, Cevâb-ı Risâle-i Şâhiye (Kasâid Münşeât ve Mürâselât), Süleymaniye Ktp. Esad Efendi, nr. 1888/3, vr. 144a-147a.

İdrîs-i Bidlîsî, Heşt Behişt, Nuruosmaniye, nr. 3209.

İdrîs-i Bidlîsî, Murâsele ila ba'zı 'uzamâ el-Acem (Kasâid Münşeât ve Mürâselât), Esad Efendi, nr. 1888/3, vr. 148a.

İdrîs-i Bidlîsî, Murâsele-i Cevâb-i Mektûb-ı Seyyidü’s-Sâdât Şeyhulislam Emîr Abdülvehhâb (Kasâid Münşeât ve Mürâselât), Süleymaniye Ktp. Esad Efendi, nr. 1888, vr. 148b-149b.

Topkapı Sarayı Müzesi Arşivi (TSMA), E. 1019.

Topkapı Sarayı Müzesi Arşivi (TSMA), E.5675.

Topkapı Sarayı Müzesi Arşivi (TSMA), E. 8333/2. 